\title{
Kimya Öğretiminde Yeni Deneysel Arayışlar: Öğretmen Adaylarının Yansıtıcı Günlükleri Ekseninde Derinlemesine Bir Bakış
}

\section{New Experimental Searches in Chemistry Education: An In-depth Look Centering on the Reflective Diaries of the Pre-service Teachers}

\begin{abstract}
Nalan AKKUZU* Hüsamettin AKÇAY ${ }^{* *}$

Öz: Bu araştırmanın amacı mikro-yansıtıcı öğretim süreci içinde kimya öğretmen adaylarının mesleki yeterliliklerinin gelişimlerine ilişkin kendi görüşlerini yansıtıcı günlükler aracılığıyla belirlemektir. Araştırmada nitel araştırma desenlerinden özel durum çalışması kullanılmıştır. Buna göre öğretmen adaylarının mikro-yansıtıcı öğretim deneyimleri sırasında mesleki yeterlilikleri ile ilgili hangi alanlarda sorun yaşadıklarına, bu sorunları nasıl çözmeye çalıştıklarına ve kendilerini hangi yönlerde geliştirdiklerine odaklanılmıştır. Araştırmanın katılımcıları altı gönüllü kimya öğretmen adayından oluşmaktadır. Uygulamada her bir öğretmen adayı seçtikleri kimya konularını 4 hafta boyunca anlatmışlardır. Veri toplama aracı olarak öğretmen adaylarının sundukları derslere yönelik görüşlerini aktaracakları yansıtıcı günlükler kullanılmıştır. Yapılan içerik analizi sonucunda öğretmen adaylarının konu alanı bilgisi, pedagoji bilgisi yeterlilikleri ve geri bildirimlerin etkisi kategorileri üzerinde durdukları ortaya çıkmıştır.
\end{abstract}

Anahtar sözcükler: Mesleki Yeterlilik, Mikro-Yansıtıcı Öğretim, Yansıtıcı Günlük, Konu Alanı Bilgisi, Pedagoji Bilgisi, Kimya Öğretmen Adayı

Abstract: The aim of this study is to determine the opinions of chemistry pre-service teachers about the development of their professional competences in their micro-reflective teaching processes through their reflective diaries. In this research, we adopted case study that is a type of qualitative research design. Accordingly, we focused on the following issues: In what fields do pre-service teachers encounter problems during their micro-reflective teaching experiences? How do they try to solve said problems? How to they try to improve themselves? Participants of the study consist of six volunteer chemistry preservice teachers. In the application stage, each pre-service teacher instructed the selected chemistry subjects for 4 weeks. We used the reflective journals on which pre-service teachers reflected their opinions concerning the courses they have instructed as the data collection tool. As a result of the content analysis we clarified that the pre-service teachers focused mostly on the categories of subject content knowledge competence, pedagogical knowledge competence and effect of feedbacks.

Keywords: Professional Competence, Micro-Reflective Teaching, Reflective Diary, Subject Content Knowledge, Pedagogical Knowledge, Chemistry Pre-Service Teacher

\footnotetext{
*Arş. Gör. Dr., Dokuz Eylül Üniv., Buca Eğitim Fakültesi, Kimya Eğitimi A.D., İzmir. nalan.akkuzu@gmail.com

** Prof. Dr., Dokuz Eylül Üniversitesi, Buca Eğitim Fakültesi, Kimya Eğitimi A.D., İzmir. husamakcay@gmail.com $\mathrm{Bu}$ çalışma danışmanlığını Prof. Dr. Hüsamettin AKÇAY'ın yaptığı Nalan AKKUZU tarafindan yazılan doktora tezinin bir bölümünden oluşmaktadır.
} 
Toplumlar, fen bilimlerindeki gelişme ve değişmelere ayak uydurabilmek için nitelikli biçimde yetiştirilmiş bireylere ihtiyaç duymaktadır. Bu anlamda yetişmiş insan gücünü sağlamanın yolu eğitimden ve bu eğitim sürecini yaşatacak mesleki yeterliliğe sahip öğretmen adaylarından geçmektedir (Shulman 1987; Üstün 2002). Öğretmen adaylarının mesleki yeterliliğe sahip olması sınıf içi deneyimler yaşaması ile mümkündür (Gilles, Cramer \& Hwang 2001; Corrigan 2006). Deneyimsel bir süreç yaşayan öğretmen adayı kendi öğretimini anlamaya çalışır, gözlemlere dayalı olarak deneyimlerinin eleştirel analizini ve değerlendirmesini yapar (Shi 2004). Öğretmen adayı deneyimler sırasında ve/veya sonrasında yansıtma sürecine girerek yaşadığı bir durumu, bir olayı ya da bir bilgiyi anlamaya ve var olan sorunu daha iyi çözmeye çalışı (Wallace 1991). Böylelikle öğretmenlik deneyimini ve mesleki yeterliliğini arttırabilir. Deneyimlerle birlikte öğretimindeki eksik ya da yanlışları gören ve yansıtıcı düşünme çerçevesinde öğretimini yeniden düzenleyen bireylerin mesleki yeterliliklerinin arttığını vurgulayan pek çok araştırmaya alanyazında rastlanılmaktadır (Lock \& Lee 2001; Rodgers 2002; Ekiz 2006; Spraker 2010; Akkuzu 2014). Öğretmen adaylarının mesleki gelişimlerini farklı bir öğretim yöntemi olan mikro-yansıtıcı öğretimi süreci içerisinde ortaya koymayı amaçlayan bu özel durum çalışması öğretmen adaylarının mesleki yeterlilikleri ile ilgili düşüncelerini yansıtmalarına odaklanmıştır.

\section{Mesleki Yeterlilik}

Mesleki yeterlilik kavramı ile ilgili alanyazında pek çok tanımla karşılaşılmaktadır. Freidson (1994) mesleki yeterlilik kavramı için "ustalık" ifadesini kullanmış ve bir mesleğin önemli bileşenlerine dikkat çekmiştir. Ustalığı, kendi işini organize etme yeterliliğine sahip olma, öz düzenleme, yeterli öğretim, beceri ve performansa sahip olma, zor ve karmaşık işlerin üstesinden gelme olarak ifade etmiştir. Tran ve King (2007) ise Freidson'ın (1994) tanımını genişleterek ustalığı, bir konu alanının iyi anlaşılmasına dayanan bir yol ve öğretimin çeşitli yöntemlerini kapsayan bir öğrenme süreci olarak ifade etmişlerdir. Alanyazın incelendiğinde, genellikle karşılaşılan tanım bir mesleğin başarılı bir biçimde yerine getirilebilmesi için sahip olunması gereken bilgi, beceri, tutum ve değerlerdir (Gül 2002; Çakan 2004; Bredekamp \& Copple 2006).

Dünyanın birçok gelişmiş ülkesinde gerçekleştirilmekte olan eğitime yönelik reformlarda fen bilimleri öğretmen adaylarının yetiştirilmesi, niteliklerinin geliştirilmesi ve mesleki yeterliliklerinin belirlenmesi amaçlanmıştır. Tüm bu çalışmalar eşliğinde geçmişten bugüne kadar uluslararası ve ulusal düzeyde öğretmenlik mesleki yeterlilik kriterleri ortaya çıarılmaya çalışı1mıştır.

\section{Uluslararası Öğretmenlik Mesleki Yeterlilik Kriterleri}

Uluslararası düzeyde bakıldığında Fen Bilimleri Öğretmeni Yetiştirme Stratejileri’nin yoğun bir şekilde tartışıldığı 1980'li yıllarda öğretmen standartları ve nitelikleri, öğretmen kalitesine yönelik çalışmalar gelişmiş, özellikle ABD ve Batı ülkelerinde farklı kuruluş ve araştırmacılar tarafından sorgulanmaya başlanmıştır. Öncelikle Shulman'ın (1987) "ögretmen bilgileri” adı altında ortaya koyduğu ve daha çok öğretmenlerin pedagojik alan bilgileri hakkındaki bilişsel anlamaları ve bu anlama ile öğrencilerine sağladıkları öğretim ve öğrenme durumları arasındaki ilişkiyi vurgulayan mesleki yeterlilik kriterleri zaman içinde farklı kuruluş (The National Board for Professional Teaching Standards [NBPTS] 2003; The National Council for Accreditiation for Teacher Education [NCATE] 2008; The National Research Council [NRC] 1996; The National Science Teachers Associaton [NSTA] 2003; The University of North Caroline at Pembroke [UNCP] 2011; Training and Development Agency for Schools [TDA] 2007) ve 
araştırmacılar (Shulman 1987; Wang 2005) doğrultusunda şekillenmiştir. Buna göre uluslararası mesleki yeterlilik kriterlerinde alan bilgisi, pedagoji bilgisi ve pedagojik alan bilgisi önemli yeterlilik bileşenlerindendir. Geliştirilen bu kriterler, öğretim deneyimlerini arttıran, yansıtıcı katılımcı rolünü üstlenen, etkili ve hayat boyu öğrenen öğretmen adaylarının niteliklerini içermektedir.

\section{Ulusal Öğretmenlik Mesleki Yeterlilik Kriterleri}

Geçmişten günümüze Türkiye'de öğretmen adaylarının yetiştirilmelerinde dünyaca kabul görmüş iki yaklaşım olan teori-pratik ve pratik-teori yaklaşımları önemli rol almış, özellikle teori-pratik yaklaşımı ön planda olmuştur (Çepni \& Azar 1995). Üniversitelerde öğretmen yetiştirmede hizmet öncesi alınan teoriye dayalı eğitimin gerçek sınıf ortamında öğrenme faaliyetleri ile ilişkilendirilmeden verilmesine dayanan teori-pratik yaklaşımının uygulanmasıyla birlikte öğretmen adaylarına mesleklerinde ya kullanılmayan ya da az kullanılan teorik bilgiden başka bir şey kazandıramayacağı sonucu ortaya çıkmıştır. Bunun sonucunda, öğretmen eğitimini yapılandırmak amacıyla Milli Eğitim Bakanlığı (MEB), üniversitelerle iş birliği yaparak "Fakülte-Okul İş Birliği Modeli" adı altında 1994-1998 yılları arasında Yüksek Öğretim Kurumu (YÖK)/Dünya Bankası (DB): Milli Eğitimi Geliştirme Projesi (MEGP) çerçevesinde öğretmenlerin hizmet öncesi eğitimleri konusunda çalışmalar yapmışlardır (Günçer 1997). Bu çalışmalardaki ana amaç, öğretmen adaylarının hizmet öncesi dönemde sınıf ortamında ihtiyaç duyduğu bilgi ve beceriyi öğretim deneyimleri ile kazanmalarıdır. Bu çalışmalar doğrultusunda öğretmen adaylarının sahip olmaları gereken yeterlilikler ve özellikleri bazı ölçütler altında belirlenmiştir (Yüksek Öğretim Kurumu [YÖK] ve Dünya Bankası [DB] 1998). Bu ölçütlere göre, öğretmen ve öğretmen adayları geniş bir dünya görüşüne ve genel kültüre sahip olmalı, öğreteceği konu alanını iyi bilmeli ve öğretme-öğrenme sürecine ilişkin bilgi ve becerilere sahip olmalıdır.

Öğretmenlik mesleğinin niteliğinin yükseltilmesi amacıyla Türkiye’de Temel Eğitime Destek Projesi (TEDP) adı altında Millî Eğitimi Geliştirme Projesi kapsamında YÖK-MEB, Öğretmen Yetiştirme ve Eğitimi Genel Müdürlüğü ve Eğitimi Araştırma ve Geliştirme Dairesi Başkanlığı (EARGED) tarafından 2002 yılında öğretmen yeterlilikleri konusunda yeniden çalışmalara başlanmıştır. Bu çalışmalar sırasında 5 ülkeye (İngiltere, ABD, Seyşel Adaları, Avustralya ve İrlanda) ait yeterlilik dokümanları bütüncül ve sistematik bir yaklaşımla incelenerek konuya ilişkin kavram ve terimler üzerinde ortak bir anlayış oluşturulmaya çalışılmıştır (Öğretmen Yetiştirme ve Eğitimi Genel Müdürlüğü [OYEGM] 2008). Öğretmen yeterliliklerinin sadece bilgiyi değil beceri ve tutumları da kapsaması gerektiği düşüncesinden yola çıkılarak çalışmalar sonrasında öğretmenlik mesleği genel yeterliliklerinin, ana yeterlilik, ana yeterliliklere ait alt yeterlilikler ve bu alt yeterliliklere ait performans göstergeleri şeklinde belirlenmesinin en uygun yöntem olacağ kararlaştırılmış ve her alan için bu yeterlilikler belirlenmiştir. Bu özel alan yeterlilikleri arasında alan bilgisi, alan eğitimi bilgisi (pedagojik alan bilgisi) ve bilimsel okuryazarlık önemli yeterlilik bileşenlerindendir.

Evrensel olarak bakıldığında mesleki yeterlilik kriterlerinin ortak bir alt yapıda toplandığı görülmektedir. Bu yeterlilik kriterleri alan bilgisi, pedagojik alan bilgisi (PAB) ve pedagoji bilgisi yeterlilikleridir (Shulman 1987; Lederman, Gess-Newsome \& Latz 1994; Temizyürek 2003). Bu kriterler göz önünde bulundurularak yapılan araştırmalara bakıldığında özellikle öğretim deneyimlerinin ve sınıf içi farklı öğrenme yaşantılarının öğretmen adaylarının mesleki gelişiminde ne tür katkılar yarattığına ve bu kriterleri nasıl kazanabileceklerine yöneliktir (Corrigan 2006; Harlow 2007; Englehart 2008; Hynes 2009; Madeira 2010). Alanyazındaki bu tür araştırmalar öğretmen adaylarının teorik bilgilerini pratiğe dönüştürebilecekleri, sınıf içi 
deneyimlerini eleştirel gözle değerlendirebilecekleri uygulamalara ihtiyaç olduğunu vurgulamaktadır. Bu noktada öğretmen adaylarının mesleki deneyimlerini yaşamalarına olanak tanıyan yansıtıcı öğretim modelleri ve uygulamaları ile sıklıkla karşılaşılmaktadır (Dewey 1933; Freire 1970; Schön 1987; Bartlett 1990; Lock \& Lee 2001; Quirk 2006; Englehart 2008; Madeira 2010; Spraker 2010; Ganesh \& Matteson 2011).

\section{Öğretim Deneyimleri İçinde Yansıtıcı Öğretim Modelinin Rolü}

Geçmişten günümüze öğretmen adaylarının mesleki yeterliliklerinin belirlenmesinde katkısı olan modeller incelendiğinde en yaygın olanların beceri, uygulanmış bilim ve yansıtıcı modeller olduğu görülmektedir (Wallace 1991; Ekiz 2003). Bu modellerden özellikle yansitıcı öğretim modeli günümüz öğretmen yeterliliklerinin belirlenmesine 1şık tutmuştur (Ekiz 2003).

Yansıtıcı öğretim modeli, bireyin kendi deneyimlerini anlamaya çalıştığı, gözlemlere dayalı olarak deneyimlerin eleştirel ve uygun analizini, değerlendirmesini yaptığı, deneyim ve bilgisini geliştirdiği bir süreçtir (Schön 1987; Shi 2004). Bu deneyimsel süreçte öğretmen adayı karmaşık bir durumla karşılaştığında öncelikle bir düşünme sürecine girer, kendi öğretimini eleştirir, sorgular ve sorunlara uygun ve gerçekçi çözümler bulmaya çalı̧arak hem mesleki yeterliliğini arttırır hem de kendi öğretimini keşfeder. Corrigan (2006), yansıtıcı düşünme sürecinin öğretmen adaylarının farklı bakış açıları altında değerlendirme yapmalarına, geri bildirimlerde bulunmalarına, gerçekleştirdikleri uygulamaları yeniden düşünmelerine ve planlamalarına olanak tanıdığını belirtmiştir.

\section{Geçmişten Günümüze Yansıtıcı Öğretim Modelleri}

Alanyazın incelendiğinde, geçmişten günümüze öğretmen adaylarının deneyimler sırasında yansıtma sürecini yaşayabileceği farklı yansıtıcı öğretim modellerinin geliştirildiği görülmektedir. Bu modeller sırasıyla Kolb'un (1984) deneyime dayalı yansıtıcı öğretim modeli, Bartlett'in (1990) beş aşamadan oluşan yansıtıcı öğretim modeli, Boud ve Walker'ın (1993) bireyin bilgi ve isteklerinin alt yapısını oluşturan bilişsel, duyuşsal ve psikomotor alanlarını kullanmaya dayalı yansıtıcı öğretim modeli, Rodgers'ın (2002), bireyin bir deneyimde bulunarak durumu kendi ve başkalarının geri bildirimleriyle birlikte gözden geçirdiği yansıtıcı öğretim modeli, Korthagen, Kessels, Koster, Lagerwerf ve Wubbels (2001)'in, ALACT adı altında eylem, geriye bakma, farkında olma, yaratma ve deneme aşamalarından oluşan yansıtıcı öğretim modeli ve Korthagen ve Vasalos'un (2005) “soğan” modelidir. Bu araştırmada Bartlett'in (1990) yansitıc1 öğretim modeli göz önünde bulundurulmuştur. Bartlett (1990), yansitıcı öğrenme-öğretme sürecini inceleme, bilgilenme, bilgileri karşılaştırma, değerlendirme ve eyleme geçirme aşamaları olmak üzere beş aşamada açıklamıştır. Burada inceleme aşaması tanımlayıcı niteliği taşırken diğer dört aşama değerlendirme, analiz etme, bilgiyi yapılandırma ve yeniden planlamayı içermektedir (Bartlett 1990). Tüm bu yansıtıcı öğretim modellerinin ortak özelliklerine bakıld1ğında bireyin bir eylemde bulunması, yaptığı eyleme yönelik düşünmesi, farklı bakış açılarından ve gözlemlerden yola çıkarak analiz etmesi ve olası çözümler üreterek yeniden eyleme geçmesi aşamalarını içermektedir. Yansıtma süreci aşamalarından geçen öğretmen adayları, öğretmenlik mesleği ile ilgili tecrübe bir başka deyişle mesleki yeterlilik kazanır. Wallace (1991), yansıtma sürecindeki öğretmen adayı bilgisinin, deneyim sonucu oluşan bilgi ve eğitim kurumlarında elde edilen kuramsal alan bilgisinden oluştuğu fikrini temel alır. Buradan hareketle mesleki yeterlilik için mesleki gelişimin yansıtma temelli modelini öne sürmektedir (Fig. 1). 

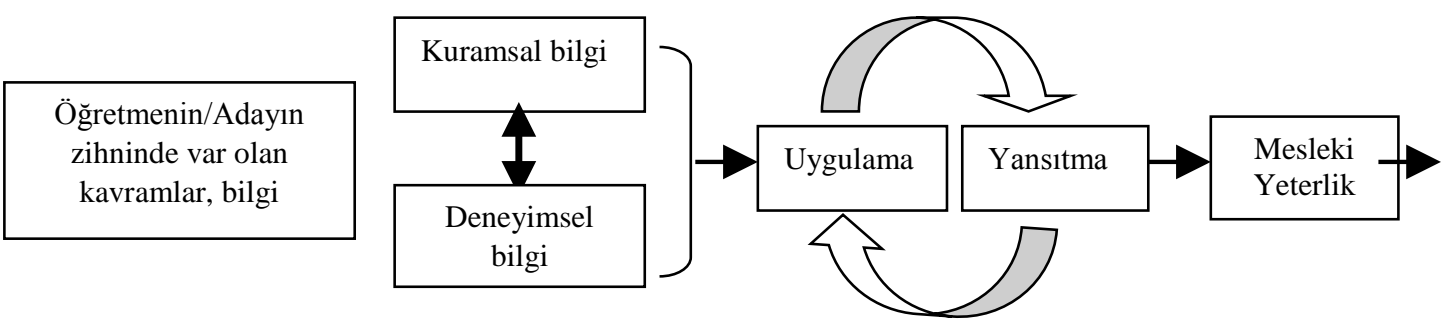

Fig. 1. Mesleki Gelişimin Yansıtma Temelli Modeli (Wallace, 1991)

Öğretmen adayları yansıtma sürecinde farklı yöntem ve araçlardan yararlanır. Bunlar, yöntem ve teknik olarak amaçlı tartışmalar, mikro-öğretim, eylem araştırmaları ve örnek olay çalışmaları iken en çok kullanılan ve etkili araçlar olarak yansıtıcı günlükler, otobiyogrofiler ve portfolyolardir (Borko, Michalec, Timmons \& Siddle 1997; Dart, Boultan-Lewis, Brownlee \& Mccrindle 1998; Krueger \& Casey 2000). Bunlardan mikro-öğretim tekniği, bir öğretmen adayının sahip olduğu teorik bilgiyi uygulama firsatı bulduğu, kendi uygulamasını hem kendi hem de uzman ve akranlarla gözlemleyerek değerlendirebildiği, mesleki gelişimi sağlayan önemli döngüsel bir süreçtir (Higgins \& Nicholl 2003). Bu süreçte, öğretmen adaylarına geniş bir deneyim imkanı sunulur ve adayın davranışlarında istenen yönde değişmeyi ve mesleki gelişmeyi sağlayacak ortam, etkinlik ve yaşantıları sağlamak temel amaçtır (Oliver 1993).

$\mathrm{Bu}$ araştırmada öğretmen adaylarının yansıtma sürecini daha etkili yaşayabilmeleri için mikro-öğretim tekniğinden faydalanılmıştır. Böylelikle yansıtıcı öğretim modeli mikro-öğretim tekniği ile birleştirilmiştir. Güney (2008), mesleki yeterliliğin kazanılmasında yansıtıcı öğretim modeline mikro-öğretim tekniğinin entegre edilmesinin, öğretmen adaylarının mesleki yeterliliklerinin arttırılmasında son derece önemli olduğunu vurgulamış ve mikro-yansıtıcı öğretim yöntemini geliştirmiştir. Bu yöntem hem mikro hem de yansıtıcı öğretimin özelliklerini taşıyan benzer bir öğretim deneyimidir. Mikro-yansıtıcı öğretim, öğrenmelerin kontrollü bir sınıf ortamında yapılandırmacı yaklaşımla kritik öğretim becerilerini geliştirme sistematiğidir. Bu öğretimle, öğretmen adayları öncelikle hazırlandıkları dersleri küçük gruplara sunmaktadırlar (Güney 2008). Öğretmen adayları, mikro öğretim deneyimlerini yaşarken yansıtıcı düşünme becerilerini de kullanarak kendi deneyimini derinlemesine düşünür ve olası çözümler bulmaya çalışır. Figür 2, mikro-öğretim ve yansıtıcı öğretim aşamalarını bir arada vermektedir.

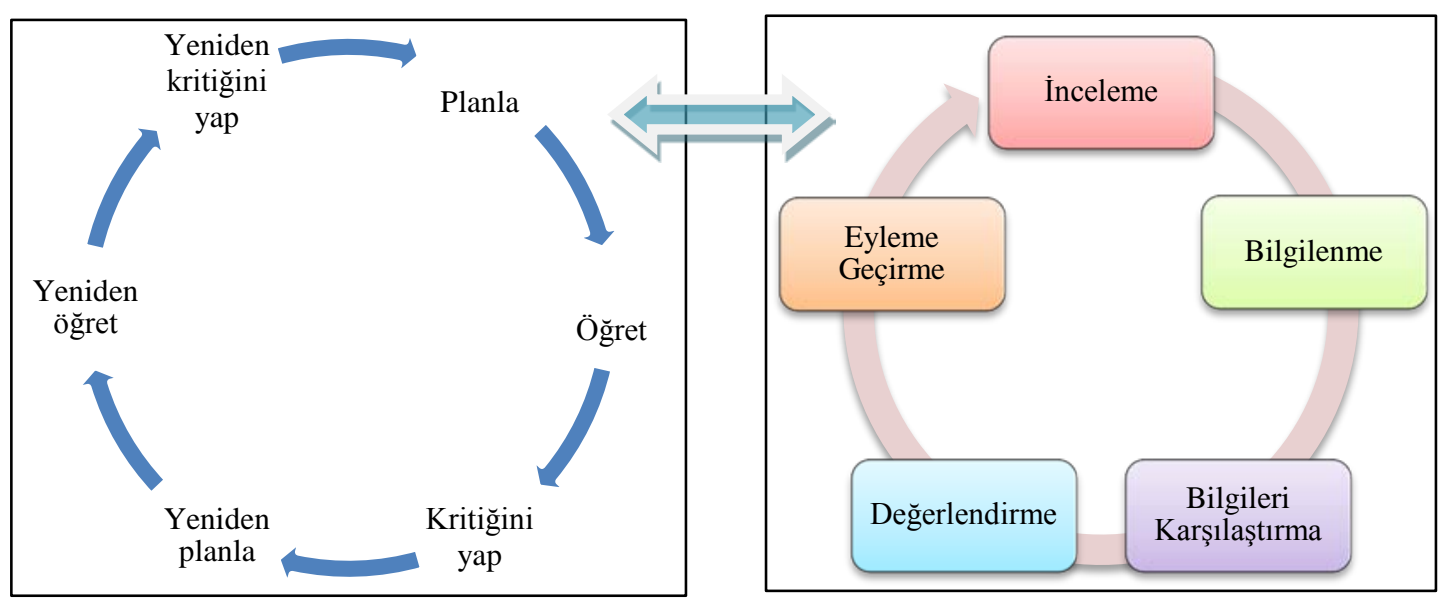

Fig. 2. Mikro-öğretim ve Yansıtıcı Öğretim Aşamaları

Mikro-öğretim sürecinde yansıtıcı öğretim aşamaları düşünmeyi yükselterek öğretme etkin- 
liklerinin yaratıcı bir biçimde düzenlenmesini sağlar. Öğretmen adayı mikro-öğretim süreci içerisinde öncelikle sunacağı ders planını hazırlar, uygulamasını yapar ve ardından kendi öğretim durumu üzerine düşünmeye başlar (Kukanauza de Mazeika 2001). Bu süreç içerisinde öncelikle yansıtıcı öğretim aşamalarından incelemede mevcut durumunu gözlemler, ikinci aşamada topladığı verilerle bilgilenir. Üçüncü aşamada ise uzman, akran ve kendi bilgilerini karşılaştırarak tartışır. Bir sonraki değerlendirme aşamasında olası çözümler ileri sürerek eyleme geçirmek için yeniden planlama yapar ve son aşamada bu olası yolları eyleme geçirir (Bartlett 1990; Rodgers 2002). Görüldüğü gibi öğretmen adayının kendi öğretim sürecini geliştirmesi, mikro-öğretim ve yansıtıcı öğretim aşamalarının birbiri içerisinde harmanlanmış bir şekilde devam etmesiyle mümkündür. Bu süreçte öğretmen adayı kavramlar ve beceriler üzerine derinlemesine düşündüğü için öğretimin bilişsel boyutunu, yansıtma sırasında tutum ve değerlerin etkisi içinde olduğu için daha çok duyuşsal boyutunu ve elde edilen bilgilere dayalı olarak devamlı deneyimler yaşadığı için psiko-motor boyutunu yaşamaktadır. Buna bağlı olarak öğretimin her üç boyutunu kapsayan böyle karma bir yöntem içinde öğretmen adayının mesleki yeterliliklerini belirlemek oldukça önemlidir. Alanyazın incelendiğinde öğretmen adaylarının mesleki yeterliliklerinin belirlendiği, mesleki gelişimlerinin ortaya konulduğu çalışmalar genellikle ya sadece mikro-öğretim uygulamalarını (Kukanauza de Mazeika 2001; Yiğit 2010) ya da yansıtıcı öğretim ortamlarını (Ekiz 2006; Farrel, Thomas \& Ives 2015) içermektedir. Bu araştırmanın alanyazındaki araştırmalardan en önemli farkı öğretmen adaylarının mesleki yeterlilikler ile ilgili eksikliklerini, yanlışlarını mikro-yansıtıcı öğretim ortamı içinde belirlemelerini sağlamak, ayrıca bu mikro-yansıtıcı süreç sonunda mesleki gelişimleri hakkındaki düşüncelerini ortaya koymaktır.

\section{Araştırmanın Amacı}

Araştırmada ana amaç mikro-yansıtıcı öğretim süreci içinde kimya öğretmen adaylarının mesleki yeterlilikleri ve gelişimlerine ilişkin görüşlerini yansıtıcı günlükler aracılığıyla belirlemektir.

\section{Yöntem}

\section{Araştırma Deseni}

$\mathrm{Bu}$ araştırmada nitel araştırma desenlerinden özel durum çalışması kullanılmıştır. Özel durum çalışması, bir ya da daha fazla olayın, ortamın, sürecin veya sosyal grubun derinlemesine incelenmesidir (McMillan 2000). Araştırmalarda durum çalışmaları, bir olayı meydana getiren ayrıntıları tanımlamak, bir olaya ilişkin olası açıklamaları geliştirmek ve bir olayı değerlendirmek amacıyla kullanılır (Gall, Borg \& Gall 1996). Bu bağlamda çalışmamız, öğretmen adaylarının mikro-yansıtıcı öğretim deneyimleri sırasında mesleki yeterlilikleri ile ilgili hangi alanlarda sorun yaşadıklarını, bu sorunları nasıl çözmeye çalıştıklarını ve kendilerini hangi yönlerde geliştirdiklerini temel alan bir özel durum araştırmasıdır.

\section{Araştırmanın Katılımcıları}

Araştırmanın katılımcılarını belirlemede amaçlı örnekleme yöntemlerinden tabakalı örnekleme yöntemi kullanılmıştır. Bu durum, araştırmaya daha farklı ve çeşitli yönlerden bakabilmeyi sağlayarak daha net sonuçların elde edilmesine olanak tanır (Patton 2001). Buradan hareketle araştırmanın katılımcıları, Türkiye’de bir devlet üniversitesinde Kimya Öğretmenliği Programının son sınıfinda okuyan ve Bahar döneminde öğretmenlik uygulaması dersine katılacak olan 26 öğretmen adayı içerisinden seçilmiştir. Öğretmen adaylarının seçimi için kişisel bilgi formu dağıtılmıştır. Kişisel bilgi formunda öğretmen adaylarına üniversitedeki akademik not ortalama- 
ları, okul dışında öğretmenlik deneyimlerinin olup olmadığı, eğer varsa sürelerinin ne olduğu ve geri bildirime yönelik düşüncelerinin neler olduğu soruları yöneltilmiştir. Formun verilmesindeki amaç, öğretmen adayları ile ilgili bilgi sahibi olmanın yanı sıra adayların çalışmanın aşamalarında gerçekleşecek geri bildirimlere ne kadar açık olup olmadıklarını belirleyerek çalışma ortamında gerçek sonuçları ortaya çıkarmak ve nitel çalışmanın güvenilirliğini sağlamaktır. Tabakalı örnekleme yöntemi doğrultusunda öğretmen adaylarının akademik not ortalamaları dikkate alınarak "iyi”, "orta” ve "zaylf" olmak üzere üç kategori oluşturulmuştur. Üniversitenin akademik not ortalaması puanı 4.00 üzerinden hesaplanmaktadır. Maksimum çeşitliliği sağlamak amacıyla her iki öğretmen adayının üç farklı düzeyde olacak şekilde seçilmelerine özen gösterilerek 4'ü erkek 2'si kız olmak üzere gönüllü toplam 6 kimya öğretmen adayı çalışmaya katılmıştır. Araştırmaya katılan öğretmen adaylarının isimleri etik olarak gizli tutulduğu için her bir öğretmen adayına "ÖA" kodu ve numara verilmiştir. Tablo 1, araştırmaya katılan 6 öğretmen adayına ait bilgileri içermektedir.

Tablo 1. Araştırmaya Katılan Öğretmen Adaylarının Özellikleri

\begin{tabular}{|l|l|}
\hline ÖA & Özellikleri \\
\hline ÖA1 & $\begin{array}{l}\text { 24 yaşındadır, düz liseden mezun olmuştur. Akademik not ortalaması 3.00'tür. } \\
\text { Yaklaşık 18 ay bir etüt merkezinde çalışmış ve bir grup öğrenciye ders vermiştir. }\end{array}$ \\
\hline ÖA2 & $\begin{array}{l}\text { 24 yaşındadır. Yabancı dil ağırlıklı lise (Süper Lise) mezunudur. Akademik not } \\
\text { ortalaması 3.10'dur. Bir devlet okulunda bir kez ders anlatmak dışında öğretmenlik } \\
\text { deneyimi yaşamamıştır. }\end{array}$ \\
\hline ÖA3 & $\begin{array}{l}\text { 25 yaşındadır. Anadolu Lisesi mezunudur. Akademik not ortalaması 2.63'tür. } \\
\text { Dershanede ve etüt merkezinde yaklaşık 9 ay çalışmıştır. }\end{array}$ \\
\hline ÖA4 & $\begin{array}{l}\text { 24 yaşındadır. Anadolu Lisesi mezunudur. Akademik not ortalaması 2.61'dir. } \\
\text { Bu zamana kadar herhangi bir öğretmenlik deneyimi yaşamamıştır. }\end{array}$ \\
\hline ÖA5 & $\begin{array}{l}\text { 25 yaşındadır. Anadolu Öğretmen Lisesi’nden mezun olmuştur. Akademik not ortala- } \\
\text { ması 2.30’dur. Yaklaşık 6 ay etüt merkezinde çalışarak bire bir öğrenciye ders anlatmıştır. }\end{array}$ \\
\hline ÖA6 & $\begin{array}{l}\text { 26 yaşındadır. Anadolu Öğretmen Lisesi mezunudur. Akademik not ortalaması 2.33' } \\
\text { tür. Yaklaş1k 7 ay kadar bir dershanede öğrenci grubuna ders vermiştir. }\end{array}$ \\
\hline
\end{tabular}

\section{Veri Toplama Araçları ve Analizi}

Araştırmada, öğretmen adayının mesleki deneyimini aktarması amacıyla yansıtıcı günlükler kullanılmıştır. Günlük tutma, uygulamanın değişik boyutlarını keşfetmeye yarayan güçlü araçlardan biridir. Öğretmen adayının kendi uygulamasını izlemede, uygulamalarının kendisi üzerindeki etkisinin ne olduğunu daha iyi anlamada ve bir sonraki uygulamaların düzenlenmesi ve planlanması için yansıtıcı günlükler oldukça önemlidir (Huey-Ling \& Gorrell 2002; Ekiz 2006). Araştırmada verilen yansıtıcı günlüklerde, Bartlett'in (1990) yansıtıcı öğretim aşamalarından yararlanılmıştır (Tablo 2).

Tablo 2. Bartlett'in Yansıtıcı Öğretim Aşamaları

\begin{tabular}{|l|l|}
\hline Aşama & Sorular \\
\hline İnceleme & Öğretmen olarak ne yapıyorum? \\
\hline Bilgilenme & $\begin{array}{l}\text { Öğretim biçimim ne ifade ediyor? Öğretim ortamındaki eylemlerimle } \\
\text { ne yapmak istedim? }\end{array}$ \\
\hline Bilgileri Karşılaştırma & Şu anki öğretim şeklimin ortaya çıkması nasıl mümkün oldu? \\
\hline Değerlendirme & Daha farklı nasıl öğretebilirim? \\
\hline Eyleme Geçirme & Şimdi nasıll öğreteceğim? \\
\hline
\end{tabular}

Yansıtıcı günlükler, her öğretmen adayına kendi sunum videosunu izledikten sonra verilmiştir. 
Öğretmen adaylarından her bir yansıtıcı günlük elektronik ortamda yazılı olarak alınmıştır. Günlükler doküman incelemesi kapsamında içerik analizine tabi tutulmuştur.

\section{Uygulama Aşaması}

Uygulama öncesinde öğretmen adaylarına mikro-yansıtıcı öğretim, uygulama süreci, Bartlett'in (1990) yansıtıcı öğretim aşamaları ve uygulanacak yansıtıcı günlükler ile ilgili 2 ders saati boyunca bilgi verilmiştir. Uygulama öncesinde aynı sınıfta yer alan farklı iki kimya öğretmen adayına iki haftalık sunum yaptırılarak pilot çalışma yapılmıştır. Pilot çalışmanın ana amacı, araştırmacı tarafından yansıtıcı günlüklerde yer alan bölümleri yeniden gözden geçirmek, öğretmen adaylarının yansıtıcı günlükleri kullanmadaki etkililiğini arttırmak, nasıl bir çalışma içerisine gireceklerine yönelik bir ön fikir edinmelerini sağlamak, sunumlardan sonra öğretmen adayının öğretimi ile ilgili geribildirimlerde bulunurken ortama alışmalarını sağlamak ve böylelikle daha samimi ve güvenilir bir ortamda tartışmayı sürdürebilmelerini sağlamaktır. Ana uygulama sürecinde öğretmen adaylarının mikro-yansıtıcı öğretim sürecindeki dersleri 4 hafta sürmüştür. Her öğretmen adayı kendi konusunu haftada bir kez sunmuştur. Araştırma, bir devlet üniversitesinin Eğitim Fakültesi'ndeki bir derslikte gerçekleştirilmiştir. Öğretmen adaylarının sunumları sırasında kendilerini rahat hissetmeleri için anlatacakları kimya konularını kendilerinin seçmeleri sağlanmıştır. Bu noktada, farklı kimya konularının olmasına dikkat edilmiştir. Gerçek sınıf ortamı yaratmak amacıyla çalışmaya gönüllü 11. sınıf 14-15 öğrenci katılmıştır. Öğretmen adaylarının anlattıkları ders konuları özetle Figür 3’te verilmiştir.

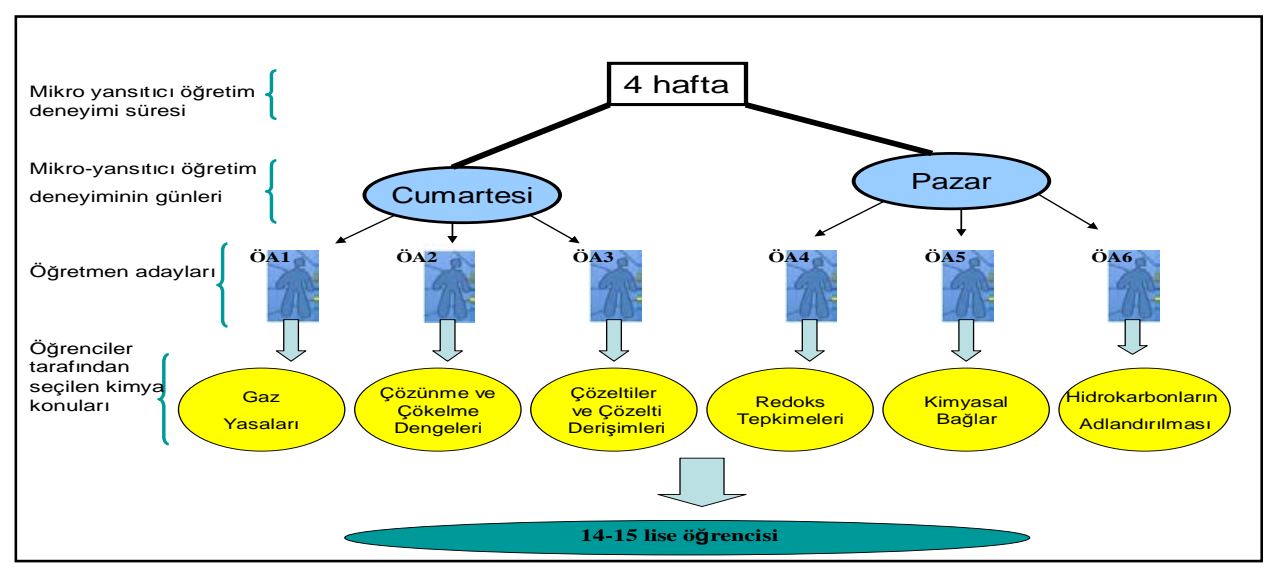

Fig. 3. Öğretmen Adaylarının Anlattıkları Ders Konuları

Öğretmen adayları, mikro-yansıtıcı öğretim sürecinde akranlarının öğretimini değerlendirmek amacıyla sunumlar sırasında yer almışlardır. Ayrıca akran değerlendirmeleri için yansıtıcı günlükler verilmiştir. Akran değerlendirmeleri için verilen yansıtıcı günlüklerde öğretmen adayı arkadaşının o günkü sunumuyla ilgili eleştirilerinin neler olduğu, mesleki yeterlilik açısından hangi alan ya da alanlarda daha yeterli ya da yetersiz olduğu, karşılaşılan problemlere yönelik alternatif çözümlerin neler olabileceği ve tavsiyelerine yönelik sorular sorulmuştur. Öğretmen adayları toplam 4 saat ders sunumu gerçekleştirmişlerdir. Her bir öğretmen adayına sunumlar için 20-30 dakikalık ders anlatma süresi verilmiştir. Öğretmen adaylarından her dersten önce sunacakları dersin planını hazırlamaları istenmiştir. Her hafta sundukları dersle ilgili düşüncelerini daha etkili bir şekilde günlüklerine yansıtabilmeleri ve dolayısıyla kendi öz-değerlendirmelerini yapabilmeleri için her ders video kaydına alınmış ve öğretmen adayları tarafından yeniden izlenmiştir. Akranlar, her ders sonrasında yansıtıcı günlüklerdeki sorulara cevap vererek değerlendirmelerini öğretmen adayına elektronik ortamda yazılı olarak sunmuştur. 


\section{Bulgular ve Yorumlar}

Araştırmanın analizi yansıtıcı günlükler üzerinden yapıldığı için bulguların sunumunda günlüklerde yer alan bölümler göz önünde bulundurulmuş ve bu bölümler altında alt kategorilere ulaşılmıştır. Öğretmen adaylarının her bir ders sonunda doldurdukları günlükler ayrı ayrı ele alınarak ortaya çıkan kategoriler tablolar şeklinde özetlenmiştir.

Tablo 3'e bakıldığında öğretmen adaylarının inceleme ve bilgilenme bölümlerinde daha çok sınıf yönetimi, konu alanı bilgisi yeterliliği ve iletişim kategorileri üzerinde durdukları görülmektedir. Bilgileri karşılaştırma bölümünde ise her bir öğretmen adayının geri bildirimlere dayalı olarak bu alanlardaki eksikliklerini fark etmekte ve bu eksikliklere dayanarak uygulamalarını değerlendirmektedir. Öğretmen adaylarından ÖA1, ÖA4, ÖA5 ve ÖA6 iletişimle ilgili kendi uygulamalarını değerlendirirken ÖA2 konu alanı bilgisi yeterliliği, ÖA3 ise materyal kullanma açısından kendini değerlendirmiştir. Eyleme geçirme aşamasında ise öğretmen adaylarının her biri eksik bulduğu, sorun yaşadığı alanla ilgili bir sonraki ders için çözüm önerisi getirmektedirler. Çözüm için ise farklı öğretim stratejisi geliştirmektedirler. Örneğin ÖA1 ve ÖA3 derse dikkat çekmek için gösterime dayanan powerpoint sunusu hazırlayacaklarını, ÖA4, deney yapacağını ve ÖA2 ise ders sırasında yaşadığı gerginliği azaltmak için materyal kullanabileceğini ifade etmiştir. Kendilerini değerlendirmede iletişime dikkat çeken ÖA5 ve ÖA6 ise bir sonraki ders için sözlü iletişime ve beden diline özen göstereceklerini belirtmiştir.

Öğretmen adaylarının 2. derse ait bulgularına bakıldığında sınıf yönetimi kategorisi altında zaman yönetimi ve dersi planlama ile ilgili sorunlar yaşadıkları görülmektedir (Tablo 4). Bunun dışında göze çarpan en önemli kategori öğretmen adaylarının çoğunun konuyu aktarmada sıkıntı yaşadıklarıdır. Örneğin ÖA2 dersinde tuzun değerliğini yanlış verdiğini, ÖA6 ise karbon atomuna altı bağ yaparak öğrencilerde kafa karışıklığına neden olduklarını ifade etmişlerdir. ÖA4 ise molekül ve bileşik kavramlarını karıştırarak öğrencilerde kavram yanılgılarına sebep olabileceğini belirtmiştir. Bulgulara bakıldığında ÖA1 dışında diğer tüm öğretmen adayları konu alanı bilgisi yeterliliklerine dair değerlendirme yapmış ve geri bildirimlerde bulunmuştur. Ortaya çıkan bu durumun nedeni öğretmen adaylarının çoğunun bir grup karşısında öğretmenlik deneyimi yaşamamasından kaynaklanabilir. Son olarak bu dersin eyleme geçirme bölümündeki bulgular incelendiğinde öğretmen adaylarının iletişim, sınıf yönetimi, konu alanı bilgisi, materyal kullanma, ölçme ve değerlendirme kategorileri üzerine yoğunlaştıkları ve bu kategorilere yönelik stratejiler geliştirmeye çalıştıkları tespit edilmiştir.

Tablo 5, öğretmen adaylarının 3. derse ait bulgularına aittir. Buna göre 2. dersten elde edilen bulgulara benzer olarak inceleme bölümünde öğretmen adaylarından ÖA2, ÖA4, ÖA5 ve ÖA6 konu alanı bilgisi kategorisi üzerinde görüşlerini ifade etmişlerdir. Öğretmen adaylarından ÖA2 konunun anlaşılmayan taraflarını öğrencilere açıklayabildiğini, yanlış yazımları düzelttiğini belirtirken ÖA6, organik bileşiklerin formüllerinde yaptığı hataları düzelttiğini ifade etmişlerdir. $\mathrm{Bu}$ durum öğretmen adaylarının mikro-yansıtıcı öğretim deneyimleri sırasında konu aktarımıyla ilgili olarak kendilerini geliştirebildiklerini göstermektedir. Bu bulguların yanı sıra öğretmen adaylarından ÖA4 ve ÖA5'in ise konu aktarımında hala sorunlar yaşadıkları tespit edilmiştir. $\mathrm{Bu}$ durum öğretmen adaylarının alan bilgilerinin eksik olmasından kaynaklanabilir. Elde edilen diğer bulgular incelendiğinde öğretmen adaylarından ÖA3'ün, simülasyon gösterisi yaparak materyal kullandığını ÖA5'in ise konu anlatımının anlaşılırlığ 1 için materyal gerektirmesine rağmen kullanamadığı saptanmıştır. Bunun dışında öğretmen adaylarından ÖA2 ve ÖA6 ölçme ve değerlendirme üzerinde durmuştur. Bilgileri karşılaştırma bölümünde her öğretmen adayının uygulamaları ile ilgili geri bildirimler yaptığı ve bunlar doğrultusunda bir sonraki dersini plan- 
ladıkları görülmektedir. Öğretmen adaylarından ÖA1, ÖA3, ÖA4 ve ÖA5 ölçme ve değerlendirme kategorisi üzerine çözümler ararken ÖA5 ayrıca materyal kullanımına, ÖA6 ise dersi farklı bir yöntemle işlemeye yönelik stratejiler geliştirmişlerdir.

Son olarak öğretmen adaylarının 4. derse ait bulguları incelendiğinde ifadelerinin daha çok ölçme ve değerlendirme kategorisi üzerinde yoğunlaştığı görülmektedir (Tablo 6). Bu kategori son ders olduğu için öğretmen adaylarının öğrencilerin önceki derslerde anlatılan konuları anlayıp anlamadıklarını tespit etmeleri dolayısıyla ortaya çıkmıştır. Bulgularda ayrıca bazı öğretmen adayları konu alanı bilgisi yeterliliğine değinmişlerdir. Örneğin ÖA2 ve ÖA5 hazırladıkları ölçme değerlendirme materyalinde yer alan sorulara anlaş1lır, yeterli ve doğru cevaplar veremediklerinden dolayı konu alanı bilgisinde sorunlar yaşadıklarını ifade etmişlerdir. ÖA2, soruları çözerken zamanı ayarlayamadığını belirtmiş ve sınıf yönetiminde aksaklıklar yaşamıştır. Öğretmen adaylarının bilgileri karşılaştırma bölümündeki ifadelerinde uygulama süresince aldıkları geri bildirimlerin kendi öğretimlerini görmek ve değerlendirmek adına faydalı olduğuna rastlanmaktadır. Eyleme geçirme bölümünde ise mikro-yansıtıcı süreç içerisinde yaşadıkları öğretmenlik deneyimlerinin mesleki yeterliliklerini arttırdığını ve ileriki ögretmenlik uygulamalarında daha profesyonel olmak için tespit ettikleri ve tamamlamaya çalıştıkları eksiklikleriyle ilgili kendilerini geliştireceklerini ifade etmişlerdir. 
Tablo 3. 1. Derse Ait Bulgular

\begin{tabular}{|c|c|c|c|}
\hline Aşama & Kategori & ÖA & Örnek Cümleler \\
\hline \multirow{4}{*}{ 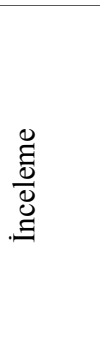 } & $\begin{array}{l}\text { Sinıf yönetimi } \\
\text { (Dikkat çekme) }\end{array}$ & $\begin{array}{l}\text { ÖA1 } \\
\text { ÖA6 }\end{array}$ & $\begin{array}{l}\text { Sınıfta oluşan bazı dikkat dağınıklarını fark edemedim. (ÖA1) } \\
\text { Dersin başında madenlerde meydana gelen patlamaların nedenlerini sordum ve açıkladım. Ders sırasında olabildiğince öğrenciyi tahtaya } \\
\text { kaldırmaya çalışım. (ÖA6) }\end{array}$ \\
\hline & Konu alanı bilgisi yeterliliği & ÖA2 & Derse odaklanamadım kısa bir süre $\mathrm{AgCl}$ tuzunun ismi aklıma gelmedi ve işin içinden tuzun sembolünü söyleyerek sıyrıldım. (ÖA2) \\
\hline & Materyal kullanma & ÖA4 & Tahtayı yanlış kullanımım vardı. (ÖA4) \\
\hline & İletişim & $\begin{array}{l}\text { ÖA3 } \\
\text { ÖA5 } \\
\text { ÖA6 }\end{array}$ & $\begin{array}{l}\text { Dikkatimi çeken en önemli nokta tahtanın önündeki hareketlerim ve konuşurkenki jest ve mimiklerim. Gayet doğala benziyor ama bazı } \\
\text { eksiklikler var mesela konuşurken öğrencilerin gözlerinin içine bakmam gerek. (ÖA3) } \\
\text { ‥ öğrenciyle diyalogum hiç olmadı. Ses tonum hep aynıdı, tonlama yapabilirdim. Bir de öğrencilere arkamı çok döndüm. (ÖA5) } \\
\text { Tahtaya çıkmaya çekinen diğer öğrencilere farklı bir tonla "korkak" dedim. (ÖA6) }\end{array}$ \\
\hline \multirow{3}{*}{ 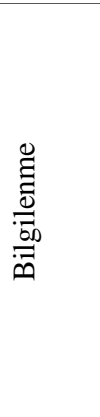 } & $\begin{array}{l}\text { Sınıf yönetimi } \\
\text { (Dikkat çekme) }\end{array}$ & $\begin{array}{l}\text { ÖA1 } \\
\text { ÖA4 } \\
\text { ÖA6 }\end{array}$ & $\begin{array}{l}\text { Konu alanı bilgisi noktasında başarılı olmama rağmen sınıf ile göz teması kurmada, sınıf yönetiminde biraz eksiklerimin olduğunu } \\
\text { gördüm. (ÖA1) } \\
\text { Tahtayı düzgün kullanmayışımdan ötürü öğrencilerin önemli kısımları kaçırmış olabileceğini düşünüyorum. (ÖA4) } \\
\text { Dersin başında madenlerde meydana gelen patlamaların nedenlerini sordum ve açıladım. Organik kimyada yer alan terimlerin günlük } \\
\text { yaşam ile ne kadar çok ilgili olduğunu öğrencilerin anlamasını sağladım.(ÖA6) }\end{array}$ \\
\hline & Konu alanı bilgisi yeterliliği & ÖA2 & Dersi anlatırken ne anlatacağıma odaklanamadım ve powerpoint sunusuna bağlı kaldım ve bir iç gerginlik yaşadım. (ÖA2) \\
\hline & İletişim & $\begin{array}{l}\text { ÖA3 } \\
\text { ÖA5 } \\
\text { ÖA6 }\end{array}$ & $\begin{array}{l}\text { Konuşurken jestlerim ve mimiklerim öğretici ve doğal olmalı. Ders anlatırken biraz havaya bakmışım öğrencilere değil...(ÖA3) } \\
\text { Ses tonum hep aynıydı, sıkıcı şekilde ders anlattım ve ögrencileri yeterince motive edemedim. Öğrencilere sürekli sırtımı dönüp tahtada } \\
\text { yazı yazmışım. Öğrencilere karşı daha samimi olabilirdim. Bu durum, iletiş̧im eksikliği yarattı. (ÖA5) } \\
\text { Öğrenciler ile konuşurken farklı noktalara bakabiliyorum bu da iletişimi azaltıcı bir etki yaratıyor. Konuşurken bazen "lllntllulı" diye } \\
\text { duraklıyorum... bunu gidermek için konuşmamı kontrol etmeliyim. (ÖA6) }\end{array}$ \\
\hline 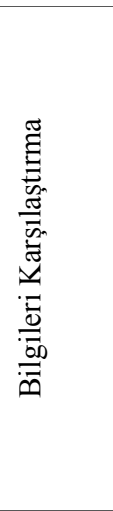 & Geri bildirimlerin etkisi & $\begin{array}{l}\text { ÖA1 } \\
\text { ÖA2 } \\
\text { ÖA3 } \\
\text { ÖA4 } \\
\text { ÖA5 } \\
\text { ÖA6 }\end{array}$ & $\begin{array}{l}\text { Birçok değerlendirmenin kesişim kümesinde tahtada soru çözerken sınıfin kontrolünü bazen kaybettiğim ve kolay ve az soru çözdüğüm } \\
\text { düşüncesi yer alıyor. Geri dönütler, soruları sȩ̧memde ve sınıf yönetimi konusunda biraz daha düşünmemi sağlamıştır. (ÖA1) } \\
\text { Sonuçları tartıştığımda ilk olarak gerginliğimi ve heyecanımı yenmem gerektiği noktasında hem fikiriz sanırım. Sonra sınıf üzerinde daha } \\
\text { iyi bir hakimiyet kurmam gerektiği noktası ve sunum sırasında sunumdan okumayı daha aza indirme noktasında hem fikiriz. (ÖA2) } \\
\text { Geri dönütlerle şunları kavradım: akıcı ve güzel Türkçe ile konuşmalı, konuşurken kendimden emin tavırlar ve jestler, mimikler } \\
\text { sergilemeli, konular arasındaki ilişkilendirmeyi mantıklı örnekler ve cümlelerle yapmalıyım. (ÖA3) } \\
\text { Akran değerlendirmeleriyle benim eksik bulduklarım genel olarak aynı... tahtada duruşumla ilgili eleştiri aldım bunu haklı buluyorum... } \\
\text { Hemen herkes biraz daha fazla soru sormam gerektiğinde hemfikirdi. (ÖA4) } \\
\text { Akran değerlendirmelerim ses tonumun aynı olması ve sınıfa çok arkamı dönmem konusunda farkına varmamı sağlamıştır. Ayrıca yüksek } \\
\text { topuklu ayakkabı giymiştim, sesin çok çıktığını ve öğrencilerin dikkatini dağıttığını ifade etmiş bir arkadaşı, hak veriyorum } \\
\text { tabi...(ÖA5) } \\
\text { Arkadaşlar öğrencilere korkak dememi olumsuz bir davranış olarak ele almışlar, ben de kısmen onlara katılıyorum... ders süresini } \\
\text { yaklaşı } 10 \text { dk aştım bu konudaki eleştirilerde de haklılar... Geri dönütler, öğrencilere karşı olan bazı ifadelerimde daha dikkatli olmam } \\
\text { ve dersi planlar iken daha dikkatli olmam gerektiğini, zamanı daha verimli kullanmam gerektiğini gösterdi. (ÖA6) }\end{array}$ \\
\hline
\end{tabular}




\begin{tabular}{|c|c|c|c|}
\hline \multirow[t]{3}{*}{ 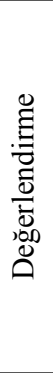 } & İletişim & $\begin{array}{l}\text { ÖA1 } \\
\text { ÖA4 } \\
\text { ÖA5 } \\
\text { ÖA6 }\end{array}$ & $\begin{array}{l}\text {... ögrencilerle göz teması kurabilirdim ve dersi daha dikkatli dinleyebilirlerdi. (ÖA1) } \\
\text { Tahtayı daha kontrollü ve sistemli kullanıp bazı şeyleri öğrencilere okuyabilirdim. Böylelikle öğrenciler tahtadan bilgileri daha kolay alırlar. } \\
\text { (ÖA4) } \\
\text { Dersi anlatırken önemli yerlerde vurgu yaparak ses tonumu değiştirebilirdim, arkamı dönmeyebilirdim, böylelikle öğrenciler sıkılmazlar ve } \\
\text { daha dikkatli ders dinlerlerdi. (ÖA5) } \\
\text { Öğrencilere onları itham edici değil de, cesaretlendirici bir konuşma yapabilirdim. Bu sayede öğrencilerin bazıları dersten kopmamış } \\
\text { olurlardı. Daha tane tane ve anlaşılır biçimde konuşmam gerekirdi. (ÖA6) }\end{array}$ \\
\hline & Konu alanı bilgisi yeterliliği & ÖA2 & Sınıfi yavaş yavaş tanımaya çalışıp ilerleyen derslerde daha geniş bir bilgi birikimi sunabilirdim. (ÖA2) \\
\hline & Materyal kullanma & ÖA3 & $\begin{array}{l}\text { Görsel sunuyla yapay bir laboratuar ortamı sunabilir ve öğrencilere tehlikesiz bir şekilde deneyleri sanal ortamda gerçekleştirme imkanı } \\
\text { sağlayarak konuyu somutlaştırır ve kalıcı öğrenmelerini sağlayabilirdim. (ÖA3) }\end{array}$ \\
\hline 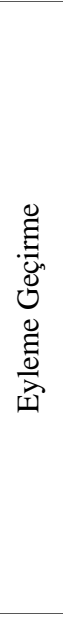 & $\begin{array}{l}\text { Öğretim stratejilerini } \\
\text { geliştirme }\end{array}$ & $\begin{array}{l}\text { ÖA1 } \\
\text { ÖA2 } \\
\text { ÖA3 } \\
\text { ÖA4 } \\
\text { ÖA5 } \\
\text { ÖA6 }\end{array}$ & $\begin{array}{l}\text { Bir sonraki dersler için sınıf yönetimi, iletişim ve materyal kullanımı konusunda kendimi geliştirmek istiyorum. Diğer derslerimi } \\
\text { görselleştirerek anlatmayı düşünüyorum. Ögrencinin dikkatini sürekli derse vermesini sağlamak adına hareketli objeler kullanmak } \\
\text { istiyorum. (ÖA1) } \\
\text { Yüksek gerginlik beni olumsuzluğa götürüyor. En çok göze batan nokta aktarım yönündeki eksiklerim..bunun için materyal } \\
\text { hazırlayabilirim...daha az gergin ve daha rahat bir atmosferde ders anlatacağım. (ÖA2) } \\
\text { Planlama, iletiş̧im, araç-gereç ve ölçme değerlendirme açısından kendimi düzeltmek istiyorum. Bir sonraki ders simulasyonla görsel bir } \\
\text { şekilde sunumumu yapacağım. (ÖA3) } \\
\text { Bir sonraki derste ölçme değerlendirmeye yönelik çalışma yapmalıyım. Derste biraz daha fazla, etkili soru sorabilirim. Bir sonraki ders için } \\
\text { bir deney tasarladım, onu yapacağım. Bruner yöntemini dersin bir kısmında kullanmış olacağım. Sonrasında yeni konuya güncel örneklerle } \\
\text { giriş yapıp bilgi kısmına geçeceğim. (ÖA4) } \\
\text { En çok iletişim, materyal kullanma, ölçme değerlendirmeye yönelik eksiklerimi gidermek istiyorum. Ses tonuma ve beden dilime özen } \\
\text { göstereceğim, öğrencilere daha çok soru sorarak daha çok ders içinde kalmalarını sağlayacağım. Biraz daha güler yüzlü olacağım. (ÖA5)... } \\
\text { derste tecrübesizliğimizden kaynaklanan tahtada sabit bir noktada durma, hizlı konuşma, öğrenciler ile fazla esprili bir dil ile konuşma gibi } \\
\text { dersin bütünlüğg̈nü bozan davranışları çok net bir biçimde görmüş oldum. Önümüzdeki ders anlatımlarında bu eksikliklerimi gidermeye } \\
\text { çalı̧acağım. Dersin zaman planlamasında bir sikıntı yaşadım ve ders süresini aştım bunu saate daha sik bakarak düzeltebilirim. Ölçme } \\
\text { değerlendirme açısından ders süresi içersinde daha fazla soru çözebilirim. Ders anlatımımda izlediğim yol öğrenciyi olabildiğince derse } \\
\text { katarak aktif hale getirmek şeklinde olacaktır. (ÖA6) }\end{array}$ \\
\hline
\end{tabular}

ÖA: Öğretmen adayı 
Tablo 4. 2. Derse Ait Bulgular

\begin{tabular}{|c|c|c|c|}
\hline Aşama & Kategori & ÖA & Örnek Cümleler \\
\hline \multirow{5}{*}{ 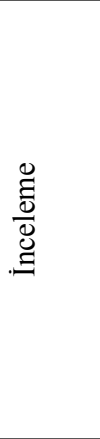 } & $\begin{array}{l}\text { Sınıf yönetimi } \\
\text { (Zaman yönetimi) }\end{array}$ & ÖA2 & $\begin{array}{l}\text { Süre aşımı sorunu yaşadım. Bir ders saati içinde kazandırmaya çalıştığım hedefleri daha uzun sürede vermek durumunda kaldım. Sunumlarda } \\
\text { önemli noktaları vurgulamalarda eksik kaldım. Farklı öğrencileri tahtaya kaldırmadım ve kaldırdığım öğrenciyi uzun süre tahtada tuttum. } \\
\text { Değerlendirme yapamadım. Deney yapacağım dedim, yapamadım. (ÖA2) }\end{array}$ \\
\hline & $\begin{array}{l}\text { Sınıf yönetimi } \\
\text { (Dersi planlama) }\end{array}$ & ÖA3 & $\begin{array}{l}\text { En belirgin özel durumum, ders programını hazırlarken hedef davranışları yoğun aldığım için dersi hızlı işlemeye çalışmamdı. Bu yüzden ders } \\
\text { konularını hızlı bir şekilde geçiştirmek zorunda kaldım. (ÖA3) }\end{array}$ \\
\hline & $\begin{array}{l}\text { Konu alanı bilgisi } \\
\text { yeterliliği }\end{array}$ & $\begin{array}{l}\text { ÖA2 } \\
\text { ÖA4 } \\
\text { ÖA5 } \\
\text { ÖA6 }\end{array}$ & $\begin{array}{l}\text { Tuzun değerliğini yanlış verdim. }\left(\mathrm{PbSO}_{4} \text { yerine } \mathrm{Pb}_{2} \mathrm{SO}_{4} \text { yazarak soru çözdüm.) (ÖA2) }\right. \\
\text { Molekül ve bileşik kavramlarını karıştırmışım, bazen molekül bazen bileşik demişim. (ÖA4) } \\
\text { Molekül geometrisinden bahsetmeden molekülün geometrisini öğrencilerden istedim. (ÖA5) } \\
\text { Tahtaya yazdığım organik molekülde br hata yaparak karbona } 6 \text { bağ yaptırdım. (ÖA6) }\end{array}$ \\
\hline & Materyal kullanma & ÖA4 & Elementlerin aktifliğinden redoks tepkimelerine geçişi yapmak için ve öğrencilerin dikkatini toplamak için deneyler yaptım. (ÖA4) \\
\hline & İletişisim & $\begin{array}{l}\text { ÖA5 } \\
\text { ÖA6 }\end{array}$ & $\begin{array}{l}\text { Tahtada ders anlatırken öğrencilere arkamı dönmedim. Vurgu ve tonlamalarıma dikkat ettim. (ÖA5) } \\
\text { Dersin bir kısmında bir elim cebimde ders anlatıyorum. (ÖA6) }\end{array}$ \\
\hline \multirow{6}{*}{ 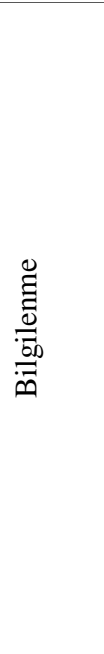 } & $\begin{array}{l}\text { Sınıf yönetimi } \\
\text { (Dikkat çekme) }\end{array}$ & $\begin{array}{l}\text { ÖA1 } \\
\text { ÖA3 }\end{array}$ & $\begin{array}{l}\text { Gelişme kaydettiğim konu olarak sınıf ile olan iletişimi söyleyebilirim. Bu da öğrencilerin ilgisini derse çekti. (ÖA1) } \\
\text { Özellikle parmak kaldırmayan öğrencileri kaldırmaya çalıştım. (ÖA3) }\end{array}$ \\
\hline & Materyal kullanma & $\begin{array}{l}\text { ÖA1 } \\
\text { ÖA4 }\end{array}$ & $\begin{array}{l}\text {...hazırladı̆̆ım animasyonlarla dersi biraz daha ilgi çekici duruma getirdim. Güncel örnekler sundum. Bunun sonucu öğrenciler sunuya baştan } \\
\text { odaklandılar ve dersin sonuna kadar dikkatleri sunumun üstünde oldu. (ÖA1) } \\
\text { Yeni konuya geçmek için deney yaptım. Öğrencilerin konuyu daha iyi anlamasını sağladı. Araç gereçlerin kullanımı açısından yeterliydim.(ÖA4) }\end{array}$ \\
\hline & $\begin{array}{l}\text { Sinıf yönetimi } \\
\text { (Zaman yönetimi) }\end{array}$ & $\begin{array}{l}\text { ÖA2 } \\
\text { ÖA4 }\end{array}$ & $\begin{array}{l}\text { Planlama yapmama rağmen süreyi ciddi şekilde aştım. Bu da değerlendirme yapamamama neden oldu. (ÖA2) } \\
\text { Soru hazırlamıştım, süreyi aşınca uygulayamadım. Dersi planlamada süre açısından yeterliliğim yok. (ÖA4) }\end{array}$ \\
\hline & $\begin{array}{l}\text { Sinıf yönetimi } \\
\text { (Dersi planlama) }\end{array}$ & ÖA6 & Dersin akışını doğru bir şekilde planladığım için ders anlatımı sırasında herhangi bir kitaba ve notlarıma bağlı kalmadan anlatabildim. (ÖA6) \\
\hline & $\begin{array}{l}\text { Konu alanı bilgisi } \\
\text { yeterliliği }\end{array}$ & $\begin{array}{l}\text { ÖA2 } \\
\text { ÖA4 } \\
\text { ÖA5 } \\
\text { ÖA6 }\end{array}$ & $\begin{array}{l}\text { Yanlış bilgi veriyorum. Konu alan bilgim iyi olduğunu düşünüyordum. Bu bilgileri aktarırken çok hata yapıyorum. Öğrencide kavram yanılgıs1 } \\
\text { oluşturduğumu düşünüyorum. (ÖA2) } \\
\text { Molekül ve bileşik kavramlarını karıştırmışım. Öğrencide kavram yanılgısına sebep olmuş olabilirim. (ÖA4) } \\
\text { Bazı formülleri yanlış yazdım ve kavramların tanımını yapmadan örnek üzerinden sordum. Konunun anlaşılamamasına neden oldu. (ÖA5) } \\
\text { Tahtaya yazdığım molekülde bir hata yaparak karbona } 6 \text { bağ yaptırdım. Bu hatanın gözümden kaçması örencilerin organik kimyanın temelini } \\
\text { oluşturan karbon atomunun yapısı ve kaç bağ yaptığı konusunda kafa karışıklığına yol açmış olabilir. (ÖA6) }\end{array}$ \\
\hline & İletişim & $\begin{array}{l}\text { ÖA3 } \\
\text { ÖA5 } \\
\text { ÖA6 }\end{array}$ & $\begin{array}{l}\text { Akıcı ve sade konuşmuyorum. Bazı kavramları dolandırarak anlatıyorum ve cümlelerimi gereksiz uzatarak öğrencinin dikkatini dağıtıyorum. (ÖA3) } \\
\text { Monoton bir ses tonu kullanmadım. Bu durum öğrencilerin daha dikkatli dinlemesini sağladı. (ÖA5) } \\
\text { Dersin bir kısmında bir elim cebimde ders anlatıyorum. Böyle ders anlatmam öğrenciler tarafından ciddiyetsizlik olarak algılanmış olabilir. (ÖA6) }\end{array}$ \\
\hline
\end{tabular}




\begin{tabular}{|c|c|c|c|}
\hline 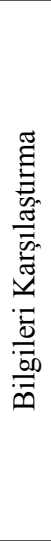 & $\begin{array}{l}\text { Geri bildirimlerin } \\
\text { etkisi }\end{array}$ & $\begin{array}{l}\text { ÖA1 } \\
\text { ÖA2 } \\
\text { ÖA3 } \\
\text { ÖA4 } \\
\text { ÖA5 } \\
\text { ÖA6 }\end{array}$ & $\begin{array}{l}\text {...Sınıf yönetimi ve iletişim konusunda ilerleme kaydettiğimi gördüm... biraz daha zor sorular hazırlamakta akranlarımla aynı düşüncedeyim. (ÖA1) } \\
\text { Konu bilgim iyi ancak aktarırken çok ciddi hatalar yapıyorum. Bunu düzeltmem gerek. Gerginlik azalmış ancak sifir gerginlikle ders anlatmam } \\
\text { gerek. Süreyi } 45 \text { dakika şeklinde kullanmam planlamayı daha iyi uygulamam gerektiğini ortaya çıkardı. Akran değerlendirmeleriyle benzerlikler } \\
\text { çok. (ÖA2) } \\
\text { Kendimde yetersiz bulduklarımla akran değerlendirmelerim aynıydı. Tartışmalar sonucu genel olarak tanımları yaparken eksik çalı̧̧ma yüzünden } \\
\text { çocukların kafalarında kavram yanılgılarına sebep olduğumu gördük. Geri dönütler ders anlatımında materyallerden yeterince faydalanmadığımı da } \\
\text { düşünmemi sağladı. (ÖA3) } \\
\text { Deney yapmam güzel ve o sırada öğrencilere soru sormam iyi... Ancak bazı kavramlardaki hatalar ve ölçme değerlendirme yapamamam büyük } \\
\text { eksiklik. Akran değerlendirmeleriyle benim eksik bulduklarım genel olarak yine aynı... hemen herkes ölçme değerlendirme yapmadığımı ifade } \\
\text { etti... bir de yine tahtada duruşumla ilgili (biraz yaslanarak durmuşum) eleştiri aldım. (ÖA4) } \\
\text { İletişim noktasında daha iyiydim. Daha motivasyonu yüksek bir dersti, ben de daha aktiftim. Akran değerlendirmelerinde de olumlu eleştiriler } \\
\text { gördüm. Ancak sadece ölçme değerlendirme ve tabi konu eksikliğim olduğu söyleniyor. Şöyle katıllyorum, konu eksikliğinden ziyade unutma } \\
\text { diyelim... Çünkü sınıf karşısında tecrübemiz olmadı̆̆ için aktarmada sıkıntı oluyor. (ÖA5) } \\
\text { Arkadaşların belirttiği ellerimi cebime sokarak ders anlatmam ve tahtadaki formülü yanlış yazmam başlıca kusurlarım olmuş. Ortak olarak } \\
\text { çıkardığımız sonuç özellikle organik bileşiklerin formüllerini yazarken daha dikkatli olmam gerektiğidir. (ÖA6) }\end{array}$ \\
\hline \multirow{4}{*}{ 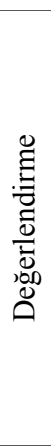 } & $\begin{array}{l}\text { Ölçme ve } \\
\text { değerlendirme }\end{array}$ & $\begin{array}{l}\text { ÖA1 } \\
\text { ÖA4 }\end{array}$ & $\begin{array}{l}\text { Sayısal işlem gerektiren formülleri anlatıp sunum arasında bu formüllerle ilgili daha zor problem çözerek pekiştirebilirdim. (ÖA1) } \\
\text { Ölçme değerlendirme için zaman ayırmalıydım ve ders planını ona göre ayarlamalıydım. (ÖA4) }\end{array}$ \\
\hline & $\begin{array}{l}\text { Sinıf yönetimi } \\
\text { (Zaman yönetimi) }\end{array}$ & ÖA2 & $\begin{array}{l}\text { Ders planına ara ara bakarak zamanlamamı kontrol edebilirdim... Deney malzemelerini, deneyi hatırlamak adına daha görünür bir yere } \\
\text { bırakabilirdim. (ÖA2) }\end{array}$ \\
\hline & $\begin{array}{l}\text { Konu alanı bilgisi } \\
\text { yeterliliği }\end{array}$ & $\begin{array}{l}\text { ÖA2 } \\
\text { ÖA3 } \\
\text { ÖA4 } \\
\text { ÖA5 } \\
\text { ÖA6 }\end{array}$ & $\begin{array}{l}\text { Dersten önce hataya mahal vermemek için ayrıntılı şekilde her şeyi gözden geçirebilirdim. Öğrencilere yanlış örnek vermezdim ve öğrencilerin } \\
\text { yanlış ögrenmelerini engellerdim. (ÖA2) } \\
\text { Geçen haftaki konuyla ilgili sorular sorduktan sonra tartışma konusu açarak beyin firtınası tekniğiyle yavaşça konuya giriş yapabilirdim.(ÖA3) } \\
\text { Kavram yanılgılarına sebebiyet vermemek için çalışmalı ve daha dikkat etmeliydim.(ÖA4) } \\
\text { Molekül geometrisinin tanımını verebilirdim. Molekül geometrisinde somut materyaller kullanabilirdim...örnek üzerinde daha iyi anlaşılırdı (ÖA5) } \\
\text { Tahtaya yazı yazarken notlarımdan yararlanmalıydım. Bu sayede formül yazmada hata yapma olasılığımı en aza indirmiş olurdum. (ÖA6) }\end{array}$ \\
\hline & İletişim & $\begin{array}{l}\text { ÖA3 } \\
\text { ÖA6 }\end{array}$ & $\begin{array}{l}\text { Daha akıcı bir şekilde kavramları net ifade ederek ders anlatabilirdim. (ÖA3) } \\
\text { Ellerim cebimde ders anlatmak yerine daha fazla bir şekilde vücut dili, jest ve mimiklerimi kullanmalıydım. (ÖA6) }\end{array}$ \\
\hline 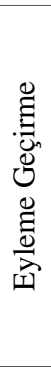 & $\begin{array}{l}\text { Öğretim } \\
\text { stratejilerini } \\
\text { geliştirme }\end{array}$ & $\begin{array}{l}\text { ÖA1 } \\
\text { ÖA2 } \\
\text { ÖA3 } \\
\text { ÖA4 } \\
\text { ÖA5 } \\
\text { ÖA6 }\end{array}$ & $\begin{array}{l}\text { Sınıf yönetimi-iletişim ve materyal kullanımı konusunda kendimi daha da geliştirmek istiyorum.. Öğrencinin dikkatini sürekli derse vermesini } \\
\text { sağlamak adına hareketli objeler kullanmak istiyorum. Bunu bu derste yaptım diğer derste de tekrarlamayı düşünüyorum. (ÖA1) } \\
\text { Farklı bir giriş yaparak dikkatleri derse çekmeği amaçlıyorum. Konuma çalışarak gelerek daha az hata yapmaya çalışacağım. Değerlendirme } \\
\text { etkinliği uygulayacağım. Süremi aşmamaya çalışacağım ve planımı daha işlevsel kullanacağım. (ÖA2) } \\
\text { Daha güzel konuşmak için okulu bitirdikten sonra diksiyon kursuna gitmeye karar verdim. Dersi planlamada daha az hedef alacağım. (ÖA3) } \\
\text { Ölçme ve değerlendirme ile ilgili uygulamalar yapmalıyım, iletişime ve dersin süresine daha çok dikkat etmeliyim. Bir sonraki derste önce aktiflikle } \\
\text { ilgili problemleri çözeceğim sonra da redoks tepkimelerini anlatıp soru üzerinde göstereceğim. (ÖA4) } \\
\text { Bu uygulama süresince ölçme ve değerlendirme yapmam gerektiğini ve konunun soyut kavramlarını vermek amacıyla materyal kullanmam } \\
\text { gerektiğini fark ettim. Ayrıca konuyu anlatırken formülleri yazmada dikkat etmem gerektiğini fark ettim. (ÖA5) } \\
\text { Öncelikle formül yazımına daha dikkat edeceğim... arada notlarımdan kontrol edeceğim. Vücut diline dikkat etmeliyim...(ÖA6) }\end{array}$ \\
\hline
\end{tabular}


Tablo 5. 3. Derse Ait Bulgular

\begin{tabular}{|c|c|c|c|}
\hline Aşama & Kategori & ÖA & Örnek Cümleler \\
\hline \multirow{3}{*}{$\begin{array}{l}\stackrel{\mathscr{\Xi}}{0} \\
\frac{\mathscr{U}}{\Xi} \\
. \Xi\end{array}$} & $\begin{array}{l}\text { Konu alanı bilgisi } \\
\text { yeterliliği }\end{array}$ & $\begin{array}{l}\text { ÖA2 } \\
\text { ÖA4 } \\
\text { ÖA5 } \\
\text { ÖA6 }\end{array}$ & $\begin{array}{l}\text { Öğrenciler Kç bağıntısını reaksiyon hızındaki denge bağıntısı olarak ifade ettiler, öğrencinin çözünürlük dengesini bilmediğini fark ettim ve } \\
\text { açılamaya çalıştım. Açıklamaları anında yaptım. Yanlıs yazımları anında düzelttim.(ÖA2) } \\
\text { Konunun devamı niteliğinde bir önceki konuyla ilişkilendirip yeni konuya geçiş yaptım. Örnekleri daha önceden seçmiş ve derste bunları farklı } \\
\text { yöntemlerle denkleştirerek anlattım ve bunu tek örnek üzerinden göstererek anlatmış oldum. Çünkü örnek seçiminde kolaydan zora doğru ilkesini } \\
\text { biraz göz ardı edip kolay olduğunu düşündüğ̈̈m, fakat öğrencilere zor gelen bir örnek seçtiğimden konunun anlatımı çok kolay olmadı. (ÖA4) } \\
\text { Her zamanki gibi klasik yöntemle ders anlattım. Bir bağ açısını yanlış yazdım, bir de bir molekülün geometrik şeklinde hata yaptım. (ÖA5) } \\
\text { Derste farklı örnekler verdim. Formüllerde bazen tek ya da çift bağ yaparak yanlış yazdım, ama bu sefer düzelttim. (ÖA6) }\end{array}$ \\
\hline & $\begin{array}{l}\text { Ölçme ve } \\
\text { değerlendirme }\end{array}$ & $\begin{array}{l}\text { ÖA2 } \\
\text { ÖA6 }\end{array}$ & $\begin{array}{l}\text { Değerlendirme kısmında öğrencilere hazırladığım “Şirinler" çalışma yaprağını uyguladım. Öğrencileri değerlendirme kısmında hızlı olmaları } \\
\text { konusunda uyardım hatta zaman yok diyerek telaşlandırdım. (ÖA2) } \\
\text { Her öğrenciyi tahtaya kaldırmaya çalıştım. (ÖA6) }\end{array}$ \\
\hline & $\begin{array}{l}\text { Materyal } \\
\text { kullanma }\end{array}$ & $\begin{array}{l}\text { ÖA1 } \\
\text { ÖA3 } \\
\text { ÖA5 }\end{array}$ & $\begin{array}{l}\text {..hazırladığım animasyonlarla dersi biraz daha ilgi çekici duruma getirdim. (ÖA1) } \\
\text { Dersin başında önceki dersin konu özetini simülasyonla yaptım. Simülasyon gösterisini örneklerle açıklayıcı şekilde anlattım. (ÖA3) } \\
\text { Materyal kullanımı olması gerekiyordu, bu konuda yine bir hazırlık yapamadım. (ÖA5) }\end{array}$ \\
\hline \multirow{5}{*}{ 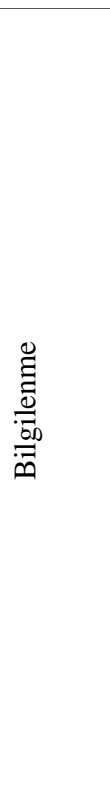 } & $\begin{array}{l}\text { Konu alanı bilgisi } \\
\text { yeterliliği }\end{array}$ & $\begin{array}{l}\text { ÖA1 } \\
\text { ÖA2 } \\
\text { ÖA3 } \\
\text { ÖA4 } \\
\text { ÖA5 } \\
\text { ÖA6 }\end{array}$ & $\begin{array}{l}\text { Çok fazla örnek sorularla dersin tam anlaşılmasını sağladım. Konu alan bilgisi konusunda yeterli olduğumu görüyorum. Çünkü konuyu anlatırken } \\
\text { günlük hayattan yine bolca örnekler verdim.(ÖA1) } \\
\text { Önemli noktaları vurgulamada daha iyi bir noktaya geldim. "altını çiziyorum" diyerek önemli noktalara dikkat çekmiş oluyorum. (ÖA2) } \\
\text { Simülasyon gösterisini örneklerle açıklayıcı bir şekilde anlattım. Çözünme kavramının kafa karıştırıcı yönlerini ortadan kaldırdı... Ders esnasında } \\
\text { konuyu akıcı anlatamama, konu alan bilgisi ve diksiyonun eksikliğindendir. (ÖA3)... zor bir örnekle başladım. Öğrenciler anlamakta zorlandılar. } \\
\text { Ben de soruyu çözmede panikledim ve uzun bir süre tahtada çözmeye çalıştım. (ÖA4) } \\
\text { Bir bağ açısını yanlış yazdım, bir de bir molekülün geometrik şeklinde hata yaptım. Öğrencilerin yanlış öğrenmesine neden oldu. (ÖA5) } \\
\text { Formül yazımımda yanlışımı düzelttiğim için öğrenciler de doğruyu gördüler ve ben yazarken daha dikkat ettiler. Bu da bir yerde onların daha } \\
\text { dikkatli dinlemelerini sağladı. (ÖA6) }\end{array}$ \\
\hline & $\begin{array}{l}\text { Sınıf yönetimi } \\
\text { (Zaman yönetimi) }\end{array}$ & $\begin{array}{l}\text { ÖA2 } \\
\text { ÖA4 }\end{array}$ & $\begin{array}{l}\text { Değerlendirmede yeterli zamanı tanımadım ve tüm sorulara erişemediler. Verdiğim çalışma yaprağındaki } 10 \text { soru için } 10 \mathrm{dk} \text { bile veremedim. (ÖA2) } \\
\text { Tahtada zor bir örnek vererek onunla uğraştım derste. Bu yüzden de ders planıma da uyamadım. Oysaki } 4 \text { farklı örnek çözecektim hem asidik ortam } \\
\text { hem de bazik ortamla ilgili, yapamadım. (ÖA4) }\end{array}$ \\
\hline & İletişim & $\begin{array}{l}\text { ÖA1 } \\
\text { ÖA2 } \\
\text { ÖA4 } \\
\text { ÖA5 }\end{array}$ & $\begin{array}{l}\text {...gelişme kaydettiğim konu olarak sınıf ile olan iletişimimde ilerleme olduğunu söyleyebilirim. Öğrencilerle sözlü iletişim artıyor git gide... } \\
\text { Sadece önemli olan noktaları vurgulamada biraz problem var. (ÖA1) } \\
\text { İfadelerimin güçlenmesiyle en çok iletişimimin geliştiğini düşünüyorum... öğrencilere kendimi dinletebiliyor ve geri dönütler alabiliyorum. (ÖA2) } \\
\text { Kendimi özellikle tahtada duruşum konusunda yeterli buluyorum. Bunun yanında ses kontrolü ve anlatma kabiliyetim de iyi. Ayrıca iletişim } \\
\text { konusunda öğrencileri de tanımaya başladığımız için daha anlaş1lı bir dil kullanıyorum. (ÖA4) } \\
\text { Göz teması, vurgulamalar iyi olduğu için iletş̧̧imim iyiydi. Ögrencilere bir şey sorduğumda aktif olarak dinlediklerini gördüm. (ÖA5) }\end{array}$ \\
\hline & $\begin{array}{l}\text { Materyal } \\
\text { kullanma }\end{array}$ & ÖA5 & Materyal kullanımı olması gerekiyordu. Moleküllerin geometrik şekilleri tam anlaşılamadı. (ÖA5) \\
\hline & $\begin{array}{l}\text { Ölçme ve } \\
\text { değerlendirme }\end{array}$ & ÖA6 & enciyi tahtaya kaldırmaya çalıştım. Böylelikle öğrencilerin tam anlamasını sağladım. Ayrıca motivasyonunu sağladım. (ÖA6) \\
\hline
\end{tabular}




\begin{tabular}{|c|c|c|c|}
\hline 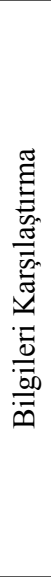 & $\begin{array}{l}\text { Geri bildirimlerin } \\
\text { etkisi }\end{array}$ & $\begin{array}{l}\text { ÖA1 } \\
\text { ÖA2 } \\
\text { ÖA3 } \\
\text { ÖA4 } \\
\text { ÖA5 } \\
\text { ÖA6 }\end{array}$ & $\begin{array}{l}\text { Bu üçüncü ders anlatımımda ilk iki anlatımıma oranla heyecanımı daha da azaltmış oldum. Ayrıca sınıf yönetimi ve iletişim konusunda da çok fazla } \\
\text { ilerleme kaydettiğimi gördüm... Akran değerlendirmelerle benzerlik olarak daha fazla deneyim kazandığım ve konu alan bilgisinde çok iyi } \\
\text { olduğumdur. Bunun dışında pek bir farklılık göremedim. Geri dönütlerin daha çok ölçme değerlendirme konusunda daha etkili ve zor soru } \\
\text { hazırlamamda ve bunu derste yansıtmamda faydası olduğunu söyleyebilirim. (ÖA1) } \\
\text { Bu derste de elimden geldiğince hatalarımı düzeltmeye çalıştım, düzelttim de. Akran değerlendirmelerinde eksiklerimi tamamladıkça benzer } \\
\text { görüşlere sahip oluyoruz. Daha önce acımasızca eleştirildiğimi düşündüğüm noktalar olmuştu, ancak zamanla haklılıklarını ben de sezdim... geri } \\
\text { dönütler genel olarak bütün yeterlilikler konusunda düşünmeme sebep oldu. (ÖA2) } \\
\text { Kimya konusunu aktarmada pasif olduğum bazı noktalar var, çalışarak onları tamamlamam gerekiyor. Akran değerlendirmelerimle benim } \\
\text { bulduklarım arasında biraz fark var. Örneğin sınıf yönetimimin yetersiz olduğunu yazmışlar. Sanırım sınıfta biraz gürültü oldu, bundan olabilir... } \\
\text { Geri dönütler ile değerlendirme, diksiyon, öğrencilere hitap, el ve yüz hareketleri, konu alan bilgisinin eksikliği ve tabi yeniden sınıfi nasıl daha iyi } \\
\text { yönetebilirim gibi yeterliliklerde kendimi geliştirmem gerektiğini anladım. (ÖA3) } \\
\text { Konuyu aktarırken seçtiğim örnek yüzünden biraz zorlandı̈... arkadaşlarım biraz telaşlandığımı yine de çok kötü olmadığımı sadece biraz fazla } \\
\text { notlarıma baktığımı söylediler. Ben de onlara katıllıorum. (ÖA4) } \\
\text { Konuyu anlatırken molekül geometrisine yönelik materyal kullanmalıydım. Akran değerlendirmeler de benzer eleştiriler yaptılar. (ÖA5) } \\
\text { Bir Powerpoint sunumu yapılabilirmiş aslında. En azından daha da çok örnek çözmek için. Bunun dışında akran değerlendirmelerimde de aynı } \\
\text { yöntemle anlatmak dışında farklı yöntemler kullanabileceğim belirtilmiş, kısmen katılıyorum. (ÖA6) }\end{array}$ \\
\hline \multirow{5}{*}{ 咅 } & İletişim & ÖA1 & Ses tonuna, önemli noktalarda vurgulamalara daha dikkat edebilirdim...(ÖA1) \\
\hline & $\begin{array}{l}\text { Materyal } \\
\text { kullanma }\end{array}$ & $\begin{array}{l}\text { ÖA1 } \\
\text { ÖA3 } \\
\text { ÖA5 }\end{array}$ & $\begin{array}{l}\text { Öğrencilerin dikkatini biraz daha çekebilecek etkinlikler düşünebilirdim. (ÖA1) } \\
\text { Simülasyonun diğer bölümlerini de gösterip çözeltilerle ilgili çocukların kafäını karıştıran bütün sorulara yanıt verebilirdim. Böylelikle sadece } \\
\text { tuzun çözünürlüğünü değil farklı maddelerin de çözünürlügünü görebilirlerdi.(ÖA3) } \\
\text { Moleküllerin geometrik şeklini powerpointten gösterebilir ya da somut materyal kullanabilirdim... örnek üzerinde daha iyi anlaş1lırdı. (ÖA5) }\end{array}$ \\
\hline & $\begin{array}{l}\text { Sinıf yönetimi } \\
\text { (Zaman yönetimi) }\end{array}$ & ÖA2 & $\begin{array}{l}\text { Verdiğim çalışma yaprağı için gerekli zamanı verebilirdim. Sorulara daha iyi odaklanabilirlerdi. Yetiştirme stresi ile çözmezlerdi. Değerlendirme } \\
\text { amacına ulaşırdı. (ÖA2) }\end{array}$ \\
\hline & $\begin{array}{l}\text { Konu alanı bilgisi } \\
\text { yeterliliği }\end{array}$ & ÖA4 & $\begin{array}{l}\text { Önce kolay bir örnekle başlayıp sonra zor bir örnek seçerek konuyu pekiştirebilirdim. Öğrenciler daha iyi anlar... zor soruyu çözmek için } \\
\text { heveslenirlerdi. (ÖA4) }\end{array}$ \\
\hline & $\begin{array}{l}\text { Ölçme ve } \\
\text { değerlendirme }\end{array}$ & ÖA6 & Ölçme değerlendirme yapılabilirdi. Bireysel farkl11ıkları görebilirdim.(ÖA6) \\
\hline \multirow{2}{*}{ 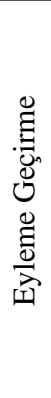 } & $\begin{array}{l}\text { Öğretim stratejisi } \\
\text { geliştirme }\end{array}$ & $\begin{array}{l}\text { ÖA2 } \\
\text { ÖA5 } \\
\text { ÖA6 }\end{array}$ & $\begin{array}{l}\text { Aktarma konusunda daha deneyimli hissediyorum kendimi, ancak daha fazla tecrübe kazanarak bu eksiğimi kapatmak için daha sık ders anlatmak } \\
\text { istiyorum. İleriki dersimde daha bir özgüvenle ve rahatlıkla dersimi sunacağım. Daha profesyonel olmaya çalı̧̧acağım. (ÖA2) } \\
\text { Bu uygulama süresince yetersiz hissettiğim noktaları artık tamamlamam gerektiğini fark ettim. Çünkü örneğin düz anlatım sadece yeterli olmadı bu } \\
\text { derste... materyal kesinlikle gerekliydi. (ÖA5) } \\
\text { Bir sonraki derste izomer konusunu işleyeceğim. Belki biraz farklı bir yöntem kullanabilirim. (ÖA6) }\end{array}$ \\
\hline & $\begin{array}{l}\text { Ölçme ve } \\
\text { değerlendirme }\end{array}$ & $\begin{array}{l}\text { ÖA1 } \\
\text { ÖA3 } \\
\text { ÖA4 } \\
\text { ÖA5 }\end{array}$ & $\begin{array}{l}\text { Bir sonraki ders için ölçme değerlendirme yapmak, daha etkili sorular yöneltmeyi ve bir başarı testi hazırlayıp uygulamayı düşünüyorum. (ÖA1) } \\
\text { Öğretim planlamam hala eksik, iletişim ve ölçme değerlendirme de öyle. Bir daha ki derste bunların peşine düşeceğim. Ölçe ve değerlendirme } \\
\text { materyali hazırlayabilirim ve yeni bir materyal kullanabilirim. (ÖA3) } \\
\text { Öğrencilerin bilişsel özelliklerine göre soruları seçmeliyim. Öğretimi planlama ile ilgili dikkat edebilirim, bir de soru düzeyi kolaydan zora olacak } \\
\text { şekilde sorular yönelteceğim. (ÖA4) } \\
\text { Hangi öğrenci ne biliyor, ne öğrendi görmeliyim... ve tabi sınıfta dolaşarak onların neler yaptığını kontrol etmeliyim. (ÖA5) }\end{array}$ \\
\hline
\end{tabular}


Tablo 6. 4. Derse Ait Bulgular

\begin{tabular}{|c|c|c|c|}
\hline Aşama & Kategori & ÖA & Örnek Cümleler \\
\hline \multirow{5}{*}{ 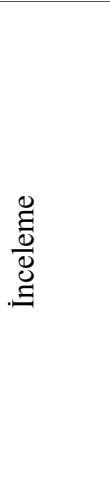 } & İletişim & ÖA1 & Daha güler yüzlü ve daha kuvvetli sözel iletişime sahip olmam dışında bir şey yok. (ÖA1) \\
\hline & $\begin{array}{l}\text { Ölçme ve } \\
\text { değerlendirme }\end{array}$ & $\begin{array}{l}\text { ÖA1 } \\
\text { ÖA2 } \\
\text { ÖA4 } \\
\text { ÖA5 }\end{array}$ & $\begin{array}{l}\text { Çok fazla örnek sorular ve hazırladığım ölçme değerlendirme testini kullandım. (ÖA1) } \\
\text { Değerlendirme kısmında her ne kadar yönerge yazılmıs olsa da öğrencilere verdiğim etkinlikte ne yapmaları gerektiğini açıklamadım. (ÖA2) } \\
\text { Bu derste bir önceki dersi telafi etmek amacıyla daha kolay örnekler çözüp, hem de bunları öğrencilere çözdürüp ölçme ve değerlendirme yapmış } \\
\text { olmayı ve konuyu pekiştirmeyi hedefledim. (ÖA4) } \\
\text { Ölçme değerlendirme materyali hazırladım ve öğrencilerle tek tek soruları çözdük... bir soruda yanlış yaptım, tabi o sıra farkına varmadım. (ÖA5) }\end{array}$ \\
\hline & $\begin{array}{l}\text { Konu alanı bilgisi } \\
\text { yeterliliği }\end{array}$ & ÖA2 & $\begin{array}{l}\text { Tuz ve iyon türleri arasındaki ilişkiyi incelediğim örnekte, powerpoint sunusundan Magnezyum florür tuzu örneğini tahtaya geçirirken altı yedi defa } \\
\text { sunuya baktım. (ÖA2) }\end{array}$ \\
\hline & $\begin{array}{l}\text { Materyal } \\
\text { kullanma }\end{array}$ & $\begin{array}{l}\text { ÖA3 } \\
\text { ÖA5 }\end{array}$ & $\begin{array}{l}\text {...derse tuzların ve şekerin çözünürlüğünü görsel bir şekilde izah eden bir materyalle başladım. Bu materyal turşu bidonu, lastik ve pamuklardan } \\
\text { yapılmış küçük toplardan oluşuyordu. Gerçekten materyal üzerinde çok fazla zaman harcanmış bir mühendislik harikasıydı. (ÖA3) } \\
\text { Klasik düz anlatımı hazırladığım powerpoint sunusuyla destekledim. (ÖA5) }\end{array}$ \\
\hline & $\begin{array}{l}\text { Öğretim stratejisi } \\
\text { geliştirme }\end{array}$ & ÖA6 & İzomer yapılarında kaynama noktasını anlatmada drama yöntemini kullandım. (ÖA6) \\
\hline \multirow{7}{*}{$\frac{\mathscr{\Xi}}{\stackrel{\Xi}{\leftrightarrows}}$} & $\begin{array}{l}\text { Ölçme ve } \\
\text { değerlendirme }\end{array}$ & $\begin{array}{l}\text { ÖA1 } \\
\text { ÖA2 } \\
\text { ÖA3 } \\
\text { ÖA4 } \\
\text { ÖA5 }\end{array}$ & $\begin{array}{l}\text { Önceki belirttiğim alanlar dışında artık ölçme ve değerlendirmede de başarılıyım. Bunu, öğrencilerin hazırladığım başarı testine verdikleri } \\
\text { cevapların doğruluğundan tespit ettim. (ÖA1) } \\
\text {...ögrencilere verdiğim etkinlikte ne yapmaläı gerektiğini açıklamadım. Bu yüzden öğrenciler sürekli soru sordu... yapılandırılmış grid tekniğine } \\
\text { bağlı olarak farklı türde sorular hazırladım. (ÖA2) } \\
\text { Bu derste bütün konuları özetleyen bir çalışma yaprağı hazırladım. Böylelikle ders anlaşılmış mı geri dönütleri az da olsa alabildim. (ÖA3) } \\
\text { daha kolay örnekler çözdüm ve öğrencilere çözdürdüm... bilgileri daha iyi pekişti ve konunun zorluğuna dair endişeleri biraz ortadan kalktı. (ÖA4) } \\
\text { Ölçme değerlendirme materyali hazırladım... Konunun anlaşılıp anlaşılmadığını gördüm ve molekül geometrisi anlaşılmamış. (ÖA5) }\end{array}$ \\
\hline & $\begin{array}{l}\text { Konu alanı bilgisi } \\
\text { yeterliliği }\end{array}$ & $\begin{array}{l}\text { ÖA2 } \\
\text { ÖA5 }\end{array}$ & $\begin{array}{l}\text { Küçük bir denklem için bu kadar çok sunuya bakmam yanlış yapma gerginliğinin bende var olduğunu gösteriyor. Ayrıca doymuş ve aşırı } \\
\text { doymuşluk kavramları ile ilgili soruyu anlamayan bir öğrenci oldu. Demek ki ders sırasında kafasındaki soru işaretlerini gideremedim. Yine ders } \\
\text { sırasında yaptığım açıklamayı yaptım... yeterli gelmedi. (ÖA2) } \\
\text { Bir soruda yanlış yaptım, tabi o sıra farkına varmadım. Öğrenci de yanlış öğrenmiş oldu ya da anlamadı. (ÖA5) }\end{array}$ \\
\hline & $\begin{array}{l}\text { Sinıf yönetimi } \\
\text { (Zaman yönetimi) }\end{array}$ & ÖA2 & $\begin{array}{l}\text { Ders planına uymak için soruların cevaplarını hızlı hızlı almak için çabaladım. Süremi aşmak istemedim. Öğrencilerin sorulara cevaplarını aceleye } \\
\text { getirdim. (ÖA2) }\end{array}$ \\
\hline & $\begin{array}{l}\text { Sinıf yönetimi } \\
\text { (Dersi planlama) }\end{array}$ & ÖA3 & Ders planını MEB müfredatına göre hazırlamada hatta normal ders planı hazırlamada eksiklerim var. (ÖA3) \\
\hline & İletişim & ÖA4 & $\begin{array}{l}\text { Öğrenciler, son dersteki rahatsızlı̆̆ımı çıkarlarına kullanıp derste gürültü yapabilirlerdi... öğrencilerim hasta olduğumu bildiklerinden bu derste daha } \\
\text { dikkatli dinleyerek bana yardımcı oldular. Bu durumun öğrencilerle olan iyi iletişimimden kaynaklandığını düşünüyorum. (ÖA4) }\end{array}$ \\
\hline & $\begin{array}{l}\text { Materyal } \\
\text { kullanma }\end{array}$ & ÖA3 & Derse hazırladığım bir materyali sunarak başladım. Öğrencilerin ilgisini çok çekti, sürekli sorular sordular. (ÖA3) \\
\hline & $\begin{array}{l}\text { Öğretim stratejisi } \\
\text { geliştirme }\end{array}$ & ÖA6 & $\begin{array}{l}\text { İzomer yapılarında kaynama noktasını anlatmada drama yöntemini kullandım... özellikle kavram yanılgısı çok olan bir konuda denedim bunu. } \\
\text { Öğrencilerde anlamayı oldukça kolaylaştırdı. Zaten ben de bu yöntemle unutmuyorum. (ÖA6) }\end{array}$ \\
\hline
\end{tabular}




\begin{tabular}{|c|c|c|c|}
\hline 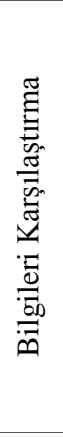 & $\begin{array}{l}\text { Geri bildirimlerin } \\
\text { etkisi }\end{array}$ & $\begin{array}{l}\text { ÖA1 } \\
\text { ÖA2 } \\
\text { ÖA3 } \\
\text { ÖA4 } \\
\text { ÖA5 } \\
\text { ÖA6 }\end{array}$ & $\begin{array}{l}\text { Sınıf yönetimi ve iletişim konusunda çok fazla ilerleme kaydettiğimi gördüm, öğrencilerle şakalaştı̆̆gm anlar da oldu. Akran değerlendirmeleri de } \\
\text { benim sonuçlarımla benzer. Başarı testi hazırlamamda akranlarla birlikte ortak bir pozitif düşünce oluşturduğumu gördüm. Onlardan aldığım geri } \\
\text { dönütler kendime olan güvenimi ve saygımı yinelememi sağlamıştır. (ÖA1) } \\
\text { Geri dönütler, genel anlamda her alanda düşünmemi sağladı. (ÖA2) } \\
\text { İlk olarak derse materyalle başlamam akıllıca idi. Bu, gençlerin derse odaklanmasını sağladı. Akran değerlendirmeleri benzer şeylerden } \\
\text { bahsediyordu. Geri dönütler, akıcı konuşmama yönelik çalışmam gerektiğini gösterdi. Planlamada eksikliğim konusunu ikinci dersten itibaren } \\
\text { biliyordum; ancak bu konuyla ilgili çok fazla bir şey yapamadım. (ÖA3) } \\
\text { Öğrencilerin dersi pekiştirmeleri için seçtiğim örnekler konuyu aydınlatıcı oldu. Ayrıca ders planıma uydum bu derste.... sadece ölçme ve } \\
\text { değerlendirme eksik diye belirtmişler... haklılar. Geri dönütlerin kendimi nasıl gördüğüme dair bir onay oldu bu ders. (ÖA4) } \\
\text { Konu alanı bilgisinde çok yeterli değilim... Bir de görsel materyaller hazırlanabilir... Akran değerlendirmelerde de benzer şeyleri gördüm. (ÖA5) } \\
\text { Akran değerlendirmeleriyle benzer sonuçlarımız var. Onlar da öğrenciyi değerlendirme dışında dersimi çok zevkli ve motivasyonun yüksek olduğu } \\
\text { görüşündeler. Ayrıca kullandığım drama yönteminin çok faydalı olduğunu hepsi söyledi. (ÖA6) }\end{array}$ \\
\hline \multirow{3}{*}{ 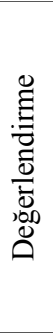 } & $\begin{array}{l}\text { Konu alanı bilgisi } \\
\text { yeterliliği }\end{array}$ & $\begin{array}{l}\text { ÖA1 } \\
\text { ÖA2 } \\
\text { ÖA5 }\end{array}$ & $\begin{array}{l}\text {...güncel örnekler araştırdım ve derste bir örnek verdim. Öğrencilerin dikkatini çekebilecek daha fazla güncel örnekler düşünebilirdim. (ÖA1) } \\
\text { Magnezyum florür örneğinde daha az sunuma bakabilirdim. Öğrencilerde öğretmen bilmiyor havası oluşmazdı. (ÖA2) } \\
\text { Konuma daha iyi çalışabilirdim. Böylelikle önceki yaptı̆̆gm hatayı burada düzeltip öğrenciye yanlış cevap vermezdim. (ÖA5) }\end{array}$ \\
\hline & $\begin{array}{l}\text { Sınıf yönetimi } \\
\text { (Zaman yönetimi) }\end{array}$ & ÖA2 & $\begin{array}{l}\text { Soruların cevaplarını almada öğrenciye yeterli zamanı tanıyabilirdim. Daha iyi sonuçlar alabilirdim ve süremi aşmamak adına ders anlatım kısmının } \\
\text { süresini ayarlayabilirdim. (ÖA2) }\end{array}$ \\
\hline & $\begin{array}{l}\text { Ölçme ve } \\
\text { değerlendirme }\end{array}$ & $\begin{array}{l}\text { ÖA2 } \\
\text { ÖA3 } \\
\text { ÖA4 } \\
\text { ÖA6 }\end{array}$ & $\begin{array}{l}\text { Öğrencilere etkinliği dağıtırken ne yapmalarına dair net bir açıklama yapabilirdim. Öğrenci çok kez soru sormazdı. (ÖA2) } \\
\text { Yaptığım ölçme değerlendirme sonunda her öğrenciyi tek tek tahtaya kaldırıp değerlendirebilirdim. (ÖA3) } \\
\text { Soru düzeyleri açısından 3. ders ile 4. dersin yerini değiştirseydim belki daha iyi olurdu. Öğrenciler daha iyi konuya adapte olabilirlerdi. (ÖA4) } \\
\text { Belki ölçme değerlendirme yapılabilirdi. Bireysel farklılıkları görebilirdim. (ÖA6) }\end{array}$ \\
\hline & $\begin{array}{l}\text { Öğretim stratejisi } \\
\text { geliş̧irme }\end{array}$ & $\begin{array}{l}\text { ÖA1 } \\
\text { ÖA2 } \\
\text { ÖA3 } \\
\text { ÖA4 } \\
\text { ÖA5 } \\
\text { ÖA6 }\end{array}$ & $\begin{array}{l}\text { Kendimi görme, izleme ve yanlışlarımı tespit etme imkanı buldum. Öğretmenlik hayatının hemen başında birçok tecrübemin arttı̆̆ını düşünüyorum. } \\
\text { En iyi ögrenmenin yaparak yaşayarak öğrenme olduğu bu anlattığımız dersler ile bir kez daha gün yüzüne çıktı. İleride sınıf yönetimi, iletişim ve } \\
\text { materyal kullanımı konusunda kendimi daha da geliştirmek istiyorum. (ÖA1) } \\
\text { Özellikle aktarma konusunda daha fazla tecrübe kazanmalıyım. Daha profesyonel olmaya çalışacağım. (ÖA2) } \\
\text { Bu çalışma benim ileriki yıllarda öğretmenlikte bana sşı olacak bir çalışma... Bu çalışmada çoğu yeterlilikleri yerine getirmeye çalıştım. Şimdi } \\
\text { zamanla daha da tecrübe edinerek, usta bir şekilde bu yeterlilikleri kullanıp öğrencilerin yararna sunmak kaldı. (ÖA3)... müfredata dikkat etmek } \\
\text { gerekli. Ben biraz konuyu öğrencilere } 4 \text { derste vermek adına sıkıştırmışoldum. Ama tabi süreyi geçirmem, öğrencilerin anlamaması gibi sıkıntılarla } \\
\text { da karşılaştım. Bir sonraki öğretmenlik deneyimlerimde bunları göz önünde bulundurarak hareket edeceğim. (ÖA4) } \\
\text { Bu uygulama süresince bazı eksikliklerimi gördüm ve tamamlamaya çalıştım. İletişim, sınıf yönetimi gibi bilgilerimi az çok tamamladım... Ancak } \\
\text { özellikle bilmeme rağmen uygulama sırasında konu alanı bilgisinin çok önemli olduğunu fark ettim. Bundan sonraki deneyimlerimde bunlara dikkat } \\
\text { ederek mesleğimi yapacağımı düşünüyorum.(ÖA5) } \\
\text { Bu uygulamada yine bazı eksiklerimi tamamladığımı düşünüyorum. Yeterlilikleri bu tür bir deneyimle kazanabileceğimi gördüm. Sınıf karşısında } \\
\text { nasıl bir öğretmen olabileceğimi daha net gördüm...Eksiklikler olsa da bunların bu tür deneyimlerle tamamlanacağını düşünüyorum. Kendimi daha } \\
\text { çok geliştirmeliyim. (ÖA6) }\end{array}$ \\
\hline
\end{tabular}




\section{Tartışma ve Sonuçlar}

$\mathrm{Bu}$ çalışmada kimya öğretmen adaylarının mikro-yansıtıcı süreç içerisinde kendi öğretim deneyimlerini izleyerek mesleki yeterlilikleri ve gelişimleri hakkında ayrıntılı görüşlerine ulaşılmaya çalışılmıştır. Öğretmen adaylarının görüşlerini belirttikleri yansıtıcı günlükler derinlemesine incelenmiş ve yansıtıcı günlüklerin her bir bölümünde çeşitli kategoriler altında toplandığı ortaya çıkmıştır. Belirtilen kategoriler aşağıda tartışılmaktadır.

\section{Konu Alanı Bilgisi Yeterliliği}

Araştırmanın bulguları incelendiğinde ortaya çıkan önemli kategori öğretmen adaylarının konu alanı bilgisi yeterliliği ile ilgilidir. Konu alanı bilgisi, herhangi bir konudaki tanımlar, denklem, formül gibi terimler, öğretim yöntemleri, konuyu açıklayıcı örnekler hakkında bilgi sahibi olmayı ve bu bilginin sınıf düzeyine uyarlanabilmesini ifade eder (Davis 2004). Bu tanımdan yola çıkılarak öğretmen adaylarının pek çoğunun anlatacakları konu ile ilgili alan bilgisi açısından sorunlar yaşadığı görülmektedir. Bu sorunlar özetle konulardaki kavram karmaşası, molekül formülünde, geometrisinde ve bağ açılarında yapılan yanlışlıklar, basitten karmaşığa ilkesine dayalı örnek sorular çözememe ve öğrencilerin sorduğu soruların cevaplarını doğru ve net açıklayamamadır. Özellikle etüt ya da dershane gibi sınıf içi öğretim deneyimi olmayan öğretmen adaylarından ÖA2, ÖA4 ve ÖA5'te bu durum daha çok ortaya çıkmaktadır. Bu bağlamda öğretim deneyimlerini yaşamanın konu alanı bilgisi yeterliliği ile ilişkisinin de oldukça fazla olduğu düşünülebilir. ÖA1, ÖA3 ve ÖA6 gibi okul dışında sınıf içi deneyim sahibi öğretmen adaylarına bakıldığında da formül yazma, öğrencilerin sorularına net ve doğru cevaplar verememe gibi bazı eksikliklerin olduğu görülmüştür. Bu noktada, öğretmen adaylarının hem alan bilgisinde sorunlar yaşadıkları hem de bilimsel bilgiyi öğretirken sınıf içinde kaygı yaşadıkları söylenebilir. Parker ve Heywood (2000), bir öğretmen adayının konu alanı bilgisinin iyi olmasını, sadece yeterli bilimsel bilgiye sahip olması ile değil aynı zamanda bu bilgiyi nasıl öğreteceğini bilmesi ile mümkün olduğunu belirtmişlerdir. Çünkü öğretmen adayının konu alanı bilgisi yeterliliği akademik düzeyde kazanmış oldukları alan bilgisinin sınıf seviyesine özgü bilgiye dönüştürülerek özelleştirilmiş bir formudur (Deng 2007). Elde edilen sonuçlar, öğretmen adaylarının mesleki deneyimleri sırasında özellikle konu alanı bilgisi ile ilgili yeterliliklerinin oldukça düşük olduğu çalışmalarla paralellik göstermektedir (Ekborg 2005; Uşak 2005; Canbazoğlu 2008). Seputro (1998), hem nitel hem de nicel araştırma tekniklerini kullandığı özel durum çalışmasında, öğretmenin konu alanı bilgisindeki yetersizliği sonucu konuyu anlatırken ezbere anlatımla birlikte farklı ve doğru olmayan yollara başvurduğunu tespit etmiş; ayrıca bu yetersizliğin karmaşık, anlaşılmayan konu aktarımlarının meydana gelmesine neden olduğunu belirtmiş̧ir. Davis (2004), konu alanı bilgisindeki yetersizliğin, güncel örnekler sunamama ve öğrencilerin sorularını yanıtlama konusunda sorunlara neden olduğunu belirtmiş; ayrıca sınırlı konu alanı bilgisi sonucunda derste gerekli olan materyallerin öğrenciye konuyla ilgili yanlış bilgi verecek şekilde kullanılmasına dikkat çekmiş̧ir. Ekborg (2005) ise yaptığı bir araştırmada öğretmen adaylarının fen bilimleri alanında kavramsal anlamaya ve yeterli bilgiye sahip olmadıklarını tespit etmiştir. Sande (2010), öğretmen adaylarının konu alanı bilgisinde yeterli olabilmeleri için sınıflara özgü kimya öğretiminde sözdizimsel yapıdaki bilgilere sahip olmaları gerektiğini belirtmiştir. Ayrıca öğretmen adayları, kimya öğretimine ilişkin olarak akademik düzeydeki alan bilgilerini çeşitli sınıf ortamlarında kullanabilmeli ve o bilgiyi dönüştürme yeterliliğine sahip olmalıdır. Böylelikle çok boyutlu bilgiye sahip olup öğrencilerin anlamasını kolaylaştırarak öğrenci ihtiyaçlarına cevap verirler (Koballa, Graber, Coleman \& Kemp 1999). Tüm bu araştırmaların sonucunda öğretmen adaylarının nitelikli öğretimi gerçekleştirmeleri için öncelikli olarak yeterli konu alanı bilgisine sahip olmaları gerekmektedir. Bir öğretmen adayı 
konuyla ilgili bilgiye ne kadar hakimse aktarması sırasında geçireceği süreç de daha dinamik ve hızlı olacaktır. Araştırmalar mesleki yeterliliğe sahip olmak ve dolayısıyla iyi bir pedagojik alan bilgisi için konu alanı bilgisinin gerekli olduğunu belirtmiştir (Fernandez-Balboa \& Stiehl 1995; Tuan 1996; Carlsen 1999; Canbazoğlu 2008).

\section{Genel Pedagoji Bilgisi}

Araştırmanın bulguları doğrultusunda ortaya çıkan diğer kategoriler iletişim, sınıf yönetimi, ölçme ve değerlendirme ve materyal kullanımıdır. Uluslararası ve ulusal düzeydeki mesleki yeterlilik kriterlerine ve araştırmalar incelendiğinde bu kategorilerin genel pedagoji bilgisi adı altında toplandığı görülmektedir (Shulman 1987; Morine-Dershimer \& Kent 1999; Mishra \& Koehler 2006; National Science Teaching Association [NSTA] 2011). Aşağıda sırasıyla bu kategoriler tartışılmıştır.

\section{İletişim}

Bulgular incelendiğinde genel pedagoji bilgisi çerçevesinde ortaya çıkan diğer önemli kategori iletişimdir. Buna göre öğretmen adaylarının her birinin öğrencilerle iletişim konusunda sorunlar yaşadığı ve bu konu üzerine kendilerini geliştirmeye çalıştıkları görülmektedir. Genellikle öğretmen adayları sinıf ortamında tahtada nasıl duracaklarını ve önemli noktaları vurgulamayı bilememekte, göz teması kuramamakta ve aktif dinleme gerçekleştirememektedirler. Öğretmen adaylarının iletişimle ilgili yaşadıkları bu sorunlar sınıf ortamında beden dilini kullanamama, konuyu aktarırken dilin yapısını kullanmadaki yetersizlik ve başarısızlıktan kaynaklanmaktadır. Araştırmalar, öğretmen adaylarının sınıf içi öğretim deneyimleri sırasında iletişim becerilerinde yeterli olmadığını göstermektedir (Edwards 1997; Çalışkan 2003; Tutkun 2015). Araştırmanın bulgularından da anlaşıldığı gibi bu durum özellikle ilk deneyimlerde öğretmen-öğrenci arasındaki etkileşime engel olmaktadır. Bu engel öğretmen adaylarının sınıf ortamında yeni karşılaştığı öğrencilerle nasıl iletişime geçeceği ve nasıl bir diyalog kurması gerektiğini bilememesinden kaynaklanabilir. Casson (2000) yaşanan bu iletişim engellerinin bireyin heyecan, kaygı, korku, utangaçlik, dinleyenleri memnun edememe gibi psikolojik durumlardan ileri geldiğini belirtmektedir. Edwards (1997), sınıf içinde öğrencilerin duygularını daha rahat ifade edebilmesi için öğretmenlerin öğrencilerini dinlerken öğrencinin söylediklerine önyargısız yaklaşmaları ve onları anlamaya çalışmaları gerektiğini ifade etmiştir. Ayrıca sınıf içi iletişimin kurulamamasının bir nedeni de öğrencilerin öğretmen adaylarını gerçek öğretmen gibi görmemelerinden kaynaklanabilir. Tschannen-Moran, Hoy ve Hoy (1998), öğretmen adaylarının öğrencilerle iletişimini yüksek yeterlik algısına dayandırmaktadır. Buna göre yüksek yeterlik algısına sahip öğretmen adayları düşük yeterlik algısına sahip olanlara göre öğrencilerle daha rahat iletişim kurmaktadırlar. Bu noktada bireylerin iletişim algılarının yüksek olması da iletişim becerilerine yönelik performanslarını olumlu yönde etkilediği düşünülmektedir. Kelly (2002), öğretmen adaylarının iletişim becerilerinin öğrencilerin bilişsel, duyuşsal ve psikolojik gelişimleri açısından diğer mesleki yeterlilikler arasında oldukça önemli bir role sahip olduğunu vurgulamaktadır. Benzer şekilde Seghedin (2012), iletişimin mesleki yeterlilikte en önemli bileşenlerden biri olduğunu ifade etmiş, ayrıca öğretmen adaylarının ilettiği mesajların yanlış anlaşılmasını önlemek için sözel, sözel olmayan iletişim ve ses tonu, aralığı ve hızı gibi iletişim biçimlerine dikkat etmeleri gerektiğini belirtmiştir. Saka ve Sürmeli (2010), araştırmalarında öğretmen adaylarının fen öğretimindeki etkililiğinin sadece öğretme yeterliliğinden değil aynı zamanda iletişim gücünün yüksek olmasından da kaynaklandığını tespit etmişlerdir. Araştırmacılar, sınıf yönetimini sağlamada iletişimin en önemli faktörlerden biri olduğunu ve öğretmen adaylarının sınıf ortamında etkili iletişim sağlayabilmesi için kişilerarası farkındalık, empati gibi 
bilişsel boyutları ve iletişim türleri, dinleme gibi davranışsal boyutları geliştirmeleri gerektiğini belirtmişlerdir (Nwogu 2000; Wubbels, Brekelmans, den Brok \& van Tartwijk 2006; Moore 2007; Gençtürk, Akbaş \& Kaymakçı 2012).

\section{Sınıf Yönetimi}

Öğretmen adaylarının uygulama sırasında üzerinde durdukları ve günlüklerine yansıttıkları diğer bir kategori ise sınıf yönetimidir. Sınıf yönetimi, öğretimin etkili ve verimli olması için gerekli koşulların oluşturulmasını sağlayan tüm etkinlik ve düzenlemelerdir (Emmer, Evertson \& Worsham 2000; Erden 2008). Araştırmadan elde edilen bulgular öğretmen adaylarının sınıf yönetimi kapsamında yaşadıkları sorunların derse dikkat çekme, zaman yönetimi ve dersi planlama olmak üzere üç boyutu üzerinde yoğunlaştığını göstermektedir. Örneğin ÖA1, sınıfta oluşan dikkat dağınıklığının nedenini araştırmış ve öğrencilerle kuramadığı etkileşimin buna neden olduğunu tespit etmiştir. Bir sonraki derslerinde iletişimini arttırarak sınıf yönetimini oluşturduğunu ifade etmiştir. Alanyazın incelendiğinde iletişimin etkili sınıf yönetimi davranışlarında anahtar rol oynadığı belirtilmektedir (Derrington \& Goddard 2008). Öğretmen adaylarından ÖA3 ise sınıftaki gürültüyü azaltmak için parmak kaldırmayan öğrencilere söz hakk1 vermiş, ÖA6 da derse dikkat çekmek için öğrencileri tahtaya kaldırmış ve günlük yaşam ile ilgili ilginç örneklere yer vermiştir. Mesleki yeterlilik kriterleriyle ilgili Missouri Öğretmen Standartlarına bakıldığında öğrencinin derse olan ilgisini arttırmanın verimli öğrenme ortamı yaratmada önemli bir etken olduğu göze çarpmaktadır (Missouri Teacher Standards [MTS] 2011). Ayrıca Wang (2005), sınıf yönetiminin öğrencileri sınıf etkinlikleri içerisine çekmek ile mümkün olabileceğini belirtmiştir. Günümüzde, yapılandırmacı yaklaşım doğrultusunda geliştirilen sınıf yönetiminde öğretmen adayına yüklenen rollerden biri öğrencilere günlük yaşamdan ilginç örnekler sunarak ve sorular yönelterek düşünmelerini ve böylelikle derse katılmalarını sağlamaktır (Barnier 2005, akt. Güneş 2007). Aynı öğretmen adaylarının yansıttığı ve etkili bir sınıf yönetiminin oluşturulmasında önemli diğer boyut ise ders planlama ile ilgilidir. Özellikle ÖA3 yoğun bir ders programı hazırlayarak bir ders saati içerisinde çok fazla kazanımı vermeye çalıştığını belirtmiş ve uygulama süresince ders planı hazırlamada eksiklerinin olduğunu fark etmiştir. Elde edilen bu bulgu Canbazoğlu'nun (2008) öğretmen adaylarıyla yaptığı çalışmanın bulgularıyla paralellik göstermektedir. Buna göre Canbazoğlu (2008), öğretmen adaylarının program bilgisi, konuya yönelik amaçlar bilgilerinin eksik olduğunu saptamış ve üniversitede ders programı ve planlaması bilgilerinin gelişmesini sağlayacak derslere önem verilmesi gerektiğini vurgulamıştır. Benzer şekilde bu araştırmada elde edilen planlama ile ilgili sorunlara dair bulgular Koç ve Yıldız'ın (2012) 19 öğretmen adayının yansıtıcı günlüklerinden elde ettiği bulgular ile tutarlılık göstermektedir. Corrigan (2006) ise öğretmen adaylarının kendi öğretim deneyimlerini değerlendirdikleri çalışmasında ders planlamasının pedagojik alan bilgisinin gelişiminde önemli bir rol aldığını dile getirmiştir. Öğretmenlik mesleği genel yeterlilikleri ve kimya öğretmeni yetiştirmede özel alan yeterlilikleri incelendiğinde ders planlamanın önemli bir kriter olduğu görülmektedir (Öğretmen Yetiştirme ve Eğitimi Genel Müdürlüğü [OYEGM] 2008). Hartzler-Miller (2002), öğretmen adaylarının öğretim deneyimleri sırasında ilk akıllarına gelenin derslerini nasıl planladıkları ve o plana göre hareket etmeleri gerektiğidir. Ders planı hazırlama, öğretimde ne öğretileceğinin öğrenciler tarafından açıkça bilinmesine ve dersin amaçlarının ortaya konulmasına yardımcı olur. Martinez-Pons (2001), öğretmenin ders planlamada sergilediği performansın öğrencinin dersteki performansına yansıdığını belirtmektedir.

Öğretmen adaylarından ÖA2 ve ÖA4'ün bulgularına bakıldığında sınıf yönetimiyle ilgili diğer bir boyut olan zaman yönetimine yönelik problemler yaşadıkları ortaya çıkmıştır. Öğretmen adaylarının her ikisi de tüm uygulama boyunca ders süresini iyi kullanamadıklarını 
belirtmişlerdir. ÖA2, planladığı bir deneyi yapamadığını, hazırladığı ölçme ve değerlendirme etkinliği için yeterli süre veremediğini ve bu yüzden doğru değerlendirmenin amacına ulaşmad1$\breve{g} ı n$ ifade ederken ÖA4 de derste anlattığı konuyla ilgili bir soruda oldukça zaman harcayarak diğer örnek soruları çözemediğini belirtmiştir. Elde edilen bu bulgu Ekiz’in (2006), öğretmen adaylarının kendi ve başkalarının öğretim uygulamalarına yönelik düşüncelerini yansıtıcı günlüklerle ortaya koyduğu çalışmasıyla paralellik göstermektedir. Ekiz (2006), öğretmen adaylarının dersi planlamalarına rağmen ders süresini aştıklarını ve dolayısıyla zamanı kullanma yönetimi konusunda zorluklar yaşadıklarını tespit etmiştir. Alanyazında öğretmen adaylarının zaman yönetimi ile ilgili yaşadıkları sorunlara ilişkin benzer bulgular yer almaktadır (Uline, Wilson \& Cordry 2004; Koç \& Yıldız 2012). Güçlü (2001), zaman yönetimini bireyin yaşadığ olayların kontrolünü sağlamak olarak ifade etmektedir. Buna göre bireyin zamanı yönetmedeki başarısı karşılaştı̆̆ olayların ne kadarını gerçekleştirebildiği ile ilgilidir. Elde edilen bulgularda ÖA2 ve ÖA4'ün zaman yönetimi konusunda sorun yaşamaları stres ve endişe içinde olmalarından kaynaklanabilir. Çünkü araştırmalar öğretmen adaylarının yaşadıkları stres ile zamanı etkili kullanamama arasında yüksek ilişki olduğunu göstermektedir (Misra \& McKean 2000; Demirtaş \& Özer 2007).

\section{Ölçme ve Değerlendirme}

Öğretmen adaylarının mikro-yansıtıcı öğretim uygulaması sırasında güçlük yaşadıklarını ifade ettikleri diğer bir alan da ölçme ve değerlendirmedir. Ölçme ve değerlendirmeyle ilgili yaşanan sorunlar genellikle öğrencilerin konuyu anlayıp anlamadıklarını tespit edememe, kolay ya da zor olarak tanımladıkları, sınıftaki öğrencilerin bilişsel düzeyine uygun olmayan sorular sorma ve öğrencilere öğrenimleri hakkında geri bildirim sağlayamamadır. Öğretmen adayları uygulama süreci içerisinde bu alanla ilgili yansıttıkları sorunların üstesinden gelmeye çalışmış ve birkaç ögretmen adayı ise alternatif ölçme değerlendirme araçları geliştirmeye çalışmışlardır. Örneğin ÖA1 son derste öğrenci düzeyine uygun başarı testi hazırlarken, ÖA2 farklı türde sorular içeren yapılandırılmış grid tekniğini kullanmıştır. Kendilerini uygulama süresince bu konuda eksik gören ÖA3 ve ÖA5 anlattıkları tüm konuları özetleyen bir çalışma yaprağı hazırlayarak öğrencilerin durumunu değerlendirmişlerdir. Bir önceki derslerinde konunun anlaşlabilirliğini zorlaştıran örnek sorular yönelten ÖA4 ise bir sonraki derslerinde basitten karmaşığa tekniğini kullanarak ölçme ve değerlendirme yapmaya çalışmıştır. ÖA6 ise derslerinde öğrencilerin durumunu daha çok tahtaya kaldırarak tespit etmeye çalışmış ancak bu durumun öğrencilerin her birinin başarılarını ayrı ayrı görmek açısından eksik kaldığını belirtmiştir. Elde edilen bulgular dikkate alındığında öğretmen adaylarının süreç içerisinde değerlendirme yapmada zorluklar yaşadıkları görülmektedir. Alanyazın incelendiğinde de öğretmen adaylarının ölçme ve değerlendirme konusunda zorluk yaşadıkları görülmektedir (Zhang \& Burry-Stock 2003; Canbazoğlu 2008; Yeşilyurt 2012). Araştırmadan elde edilen bulguya paralel olarak Koç ve Yıldız (2012) öğretmen adaylarının öğretim süreci içerisinde etkili sorular soramadıklarını ve öğrenci düzeyinden daha yüksek düzeyde sorular sorduklarını tespit etmişlerdir. Zhang ve Burry-Stock (2003), ölçme ve değerlendirmedeki eksiklikleri pedagoji bilgisindeki eksikliğe dayandırmış, üniversitede alınan ders miktarı ve deneyimler arttıkça bireylerin kendilerini daha yeterli hissedeceklerini belirtmişlerdir. Ayrıca bazı araştırmalar, öğretmen adaylarının bu konudaki negatif algılarının öğretim uygulamalarında yapacakları değerlendirmelere olumsuz bir şekilde yansiyabileceğini ortaya koymuştur (Childs \& Lawson 2003; Volante \& Fazio 2007). Linn ve Grounland (2005), ölçme ve değerlendirmenin öğretimi tamamlayan bir süreç olduğunu, iyi planlanırsa etkili bir öğrenme gerçekleşeceğini belirtmişlerdir. 


\section{Materyal Kullanma}

Öğretmen adaylarının bir bölümünün yansıttığı diğer önemli bir kategori de materyal seçimi ve kullanımı ile ilgilidir. Öğrencilerin ders kazanımlarını elde etmelerinde öğretim strateji ve yöntemlerine dayalı olarak materyallerin belirlenmesi oldukça önemlidir (Yalın 2004). Araştırmanın bulguları incelendiğinde öğretmen adaylarından sadece ÖA4'ün tahtayı kullanamadığına dair ifadeleri bulunmaktadır. ÖA4 bir sonraki dersinde öğrencilere aktiflik ve redoks tepkimeleri konuları ile ilgili deneysel tasarım hazırlamış ve sınıfta uygulamıştır. Bunun dışında öğretmen adaylarından ÖA1 öğrencilerin dikkatini derse çekmek amacıyla gaz yasalarını anlatırken öğretici animasyonlardan faydalanmış, ÖA3 ise simülasyon kullanarak bilgisayar yardımıyla çözünme kavramını öğretmeye çalışmıştır. Ayrıca ÖA3 son dersinde tuzun ve şekerin çözünürlüğünü anlatmak amacıyla bir materyal geliştirmiştir. ÖA5, her ders sonrasında yansitıcı günlüklerinde kimyasal bağlarda moleküllerin geometrik şekilleri konusunu öğretirken materyal kullanmanın gerekliliğinden bahsetmiş ancak bu konuyla ilgili herhangi bir girişimde bulunmamıştır. Elde edilen bu bulgular, öğretmen adaylarının bir bölümünün uygulama etkinliklerinde öğrenmeyi kolaylaştırıcı öğretim materyallerine yer verdiklerini ancak diğer öğretmen adaylarının materyal hazırlayamadıkları ve bu konuda zorlandıklarını göstermektedir. Benzer bulguya Koç ve Yıldız'ın (2012) çalışmasında rastlanılmaktadır. Davis (2004), öğretmen adaylarının materyal kullanmamasını konu alanı bilgilerindeki yetersizliğe dayandırmaktadır. Sınırlı konu alanı bilgisine sahip öğretmen adaylarının materyal kullanımında rahat olmadıklarını ve öğrenciye konuyla ilgili yanlış bilgi verecek şekilde kullanabileceklerini belirtmiştir. Araştırmalar, fen öğretiminde öğrencilerde istendik davranışları oluşturmak ve dolayısıyla dersin kazanımlarını elde etmelerini sağlamak amacıyla uygun stratejiye yönelik materyalleri seçmenin önemli olduğunu belirtmiştir (Baillie \& Vanasupa 2003; Yalın 2004).

\section{Geri Bildirimlerin Etkisi}

Öğretmen adaylarının yansıtıcı günlüklerinden ortaya çıkan bir diğer kategori geri bildirimlerin etkisidir. Bu kategori öğretmen adaylarının bilgileri karşılaştırma bölümünde ortaya çıkmıştır. Öğretmen adayları bu bölümde hem kendi öz değerlendirmelerinden hem de akran değerlendirmelerinden oluşan geri bildirimleri dikkate alarak öğretimlerini gözden geçirmişlerdir. Öğretmen adaylarının aldıkları geri bildirimler incelendiğinde daha çok konu alanı bilgisi, iletişim, ölçme ve değerlendirme, sınıf yönetimi ve materyal kullanma alanları üzerine yoğunlaşmaktadır. Aldıkları bu geri bildirimler sayesinde öğretim uygulamalarının hem güçlü hem de eksik yönlerini tespit etmişlerdir. Araştırmalar, öğretmen adaylarının performanslarını sergiledikleri öğretim deneyimleri sırasında kendi öğretimlerindeki eksikliklerin ya da yanlışlıkların farkındalığını arttırmada geri bildirimin önemli bilgi aracı olduğunu göstermektedir (Kukanauzau de Mazeika 2001; Hattie \& Timperley 2007; Usher \& Pajares 2008; Ekşi 2012; Akkuzu 2014). Araştırmaya katılan tüm öğretmen adaylarında geri bildirimlerin etkisi ile bu farkındalık oluşmuş ve farklı alternatif çözümler bulmaya çalışmışlardır. Bu nedenle geri bildirimlerin bir sonraki öğretim uygulamaları için geliştirici nitelikte olduğunu vurgulamışlardır. Alanyazın incelendiğinde geri bildirimlerin farklı düşünme yollarına başvurmaya yardımcı olduğu ve böylelikle mesleki gelişime katkıda bulunduğu görülmektedir (Ekiz 2006; Harford \& MacRuaric 2008; Madeira 2010). Bezzina (2006), öğretmen eğitiminin sadece 'yetiştirme' boyutunu değil aynı zamanda 'gelişme' boyutunu içerdiğini ifade etmiştir. Bu bağlamda gelişimin iyi bir teorik bilgi ve öğretmenlik uygulamasının yanı sıra uygulama faaliyetlerinin eleştirel bir bakış açısıyla değerlendirilebildiği geri bildirimler ile mümkün olduğunu belirtmiş̧tir. 


\section{Öğretim Stratejisi Geliştirme}

Araştırma bulgularında göze çarpan bir diğer kategori de öğretim stratejisi geliştirmedir. Bu kategori öğretmen adaylarının bir sonraki ders için yansıttıkları eyleme geçirme bölümünde ortaya çıkmıştır. Bu noktada öğretmen adayları deneyimleri sırasında karşılaştıkları sorunlarla ilgilenerek, bunlara uygun ve gerçekçi çözümler üretmeye çalışmışlardır. Bu doğrultuda etkin, amaçlı ve istikrarlı düşünme sürecine girmişlerdir. Elde edilen bulgular öğretmen adaylarının etkili bir uygulama gerçekleştirebilmelerinin izleyecekleri stratejilere dayalı olduğunu göstermektedir. Her bir öğretmen adayı öğretimindeki eksik ve/veya zayıf yönleri dikkate alarak bir sonraki ders için uygun strateji geliştirmeye çalışmıştır. Öğretmen adaylarının geliştirdiği stratejiler konu alanı bilgisi, iletişim, ölçme ve değerlendirme, sınıf yönetimi ve materyal kullanma alanları üzerine yoğunlaşmaktadır. Öğretmen adaylarının bu alanlarda uygun stratejiler ortaya koymaları etkili bir kimya öğretimi süreci için dersin kazanımlarına ulaşmayı sağlama mücadelesiyle ilgilidir. $\mathrm{Bu}$ esnada birey deneyimlerine anlam vererek sahip olduğu bilgiyi dönüştürme ve değiştirme aşamasına geçmektedir (Kolb 1984). Lee, Brown, Luft ve Roehring (2007), öğretmen adaylarının öğretimleriyle ilgili olarak sınıflarda bilinçsizce davranabildiklerini ve bu yüzden sürekli strateji geliştirmeleri gerektiğini belirtmişlerdir.

Araştırmanın ortaya çıkan tüm sonuçları incelendiğinde öğretmen adaylarının mikroyansıtıcı öğretim uygulamaları sırasında konu alanı bilgisi, iletişim, ölçme ve değerlendirme, sınıf yönetimi ve materyal kullanma alanlarında sorunlar yaşadıkları ve mesleki açıdan bu alanlarda kendi eksik bilgilerinin farkına vararak bunları tamamlamaya, yanlış bilgilerini düzeltmeye çalıştıkları ve iyi olan yönlerini de keşfettikleri görülmüştür. Araştırma sonuçları, öğretmen adaylarının bu yansıtma süreci içinde öğretimlerine yönelik değerlendirmeler yaparak bir sonraki derslerini tekrar düzenlediklerini ve karşılaşılan problemlerin üzerine eğilerek üstesinden gelmeye çalıştıklarını göstermiştir. Bu doğrultuda öğretim deneyimlerinin farkındalığını arttırmak ve bilinçli çözümler üretebilmek amacıyla yansıtma sürecinin her bir aşamasının önemli olduğu söylenebilir.

\section{Öneriler}

Araştırma sonuçlarından hareketle kimya öğretmen adaylarının mesleki yeterliliklerini geliştirebilmeleri için sınıf ortamında çok sayıda deneyimleri yaşamalarına olanak sağlayan mikro-yansıtıcı öğretim süreçlerine yer verilmelidir. $\mathrm{Bu}$ tür yansitıcı ortamlarda öğretmen adayları öncelikle anlatacakları konularda yer alan kavramları doğru kullanabilme, denklemleri, molekül formülleri ve geometrilerini doğru yazabilme, öğrencilerin sorularına doğru ve açıklayıc1 cevaplar verebilme, konular arası ilişkilendirmeyi yapabilme, güncel örnek olaylarla konuları bağdaştırabilme ve basitten karmaşı̆ğa ilkesine dayalı örnek sorular çözebilme becerilerini içeren konu alanı bilgisi yeterliliklerini arttırabilirler. Ayrıca mikro-yansıtıcı öğretim sürecinde öğretmen adaylarının teoride öğrendikleri iletişim, ölçme ve değerlendirme, sınıf yönetimi ve materyal kullanma gibi genel pedagoji bilgilerini uygulamaya nasıl geçirdiklerini izlemeleri, bu izlenimler sırasında kendi eksiklerini değerlendirmeleri ve kendilerini geliştirmeleri sağlanabilir. Öğretmen adaylarının mesleki açıdan gelişmelerini sağlayan bu tür mikroyansıtıcı ortamlar, adayların aynı zamanda yüksek öz yeterliliğe sahip bireyler olarak yetişmelerine olanak tanır. Bu nedenle uygulama okullarına giden öğretmen adaylarının özellikle sınıf ortamında çeşitli mikro-yansıtıcı öğretim modellerine dayalı olarak konularını işlemeleri sağlanabilir. Uygulama okullarında kendi öğretimlerindeki eksikliklerini ya da yanlışlarını fark eden öğretmen adayları değerlendirmelerinden ortaya çıkan sonuçları içselleştirebilir ve karşılaştıkları sorunların üstesinden gelebilirler. Ayrıca yansıtma sürecinin içinde olan öğretmen adayları kendi öğretimleriyle ilgili geri bildirimlerin etkisiyle çeşitli öğretim stratejileri gelişti- 
rebilirler. Bunlardan farklı olarak çeşitli yansıtıcı öğretim modellerinin mikro-öğretim tekniğine entegre edilmesiyle oluşan yeni mikro-yansıtıcı öğretim süreçlerinin öğretmen adaylarının mesleki yeterlilik kriterlerini sağlamada etkililiği araştırılabilir.

\section{KAYNAKÇA}

Akkuzu N. (2014). "The Role of Different Types of Feedback in the Reciprocal Interaction of Teaching Performance and Self-Efficacy Belief”. Australian Journal of Teacher Education 39/3 (2014). Doi: http://dx.doi.org/10.14221/ajte.2014v39n3.3.

Baillie C. \& Vanasupa L. (Eds.). (2003). Navigating the Materials World. London 2003.

Bartlett L. (1990). "Teacher Development Through Reflective Teaching”. Eds. J.C. Richards \& D. Nunan. Second Language Teacher Education (1990) 202-214. New York.

Bezzina C. (2006). "Views from the Trenches: Beginning Teachers' Perceptions about Their Professional Development”. Journal of In-Service Education 32 (2006) 411-430. Doi: 10.1080/1367458060102 4515.

Borko H., Michalec P., Timmons M. \& Siddle J. (1997). "Teaching Portfolios: A Tool for Promoting Reflective Practice”. Journal of Teacher Education 48/5 (1997) 345-358.

Boud D. \& Walker D. (1993). "Barriers to Reflection on Experience". Eds. D. Boud, R. Cohen. \& D. Walker. Using Experience for Learning (1993) 73-86. Buckingham.

Bredekamp S. \& Copple C. (2006). Basics of Developmentally Appropriate Practice: An Introduction for Teachers of Children 3 to 6. Washington, DC 2006.

Canbazoğlu S. (2008). Fen Bilgisi Öğretmen Adaylarının Maddenin Tanecikli Yapısı Ünitesine İlişkin Pedagojik Alan Bilgilerinin Değerlendirilmesi. Yüksek Lisans Tezi. Gazi Üniversitesi Eğitim Bilimleri Enstitüsü, Ankara 2008.

Carlsen W. S. (1991). “Subject-Matter Knowledge and Science Teaching: A Pragmatic Perspective”. Ed. J. Brophy. Advances in Research on Teaching: Vol. 2. Teachers' Knowledge of Subject Matter as it Relates to Their Teaching Practice (1991) 115-143.Greenwich, CT.

Casson H. N. (2000). Söz Söyleme Sanatı. Çev. V. Yılmaz. İstanbul 2000.

Cevher-Kalburan N. (2014). "Early Childhood Pre-Service Teachers' Concerns and Solutions to Overcome Them (The Case of Pamukkale University)". South African Journal of Education 34/1 (2014) 1-18.

Childs R. A. \& Lawson A. (2003). "What do Teacher Candidates Know about Large-Scale Assessments? What should They Know?”. Alberta Journal of Educational Research 49/4 (2003) 354-367.

Corrigan D. (2006). "Preparing Teachers of Chemistry for a Global Market". Ed. Mary B. Klein. New Teaching and Teacher Issues (2006) 141-162. New York.

Çakan M. (2004). "Öğretmenlerin Ölçme-Değerlendirme Uygulamaları ve Yeterlilik Düzeyleri: İlk ve Ortaöğretim”. Ankara Üniversitesi Eğitim Bilimleri Fakültesi Dergisi 37/2 (2004) 99-114.

Çalışkan N. (2003). Sinıf Öğretmenlerinin Sözel Olmayan İletişim Davranışlarının Değerlendirilmesi. Yayınlanmamış Doktora Tezi. Atatürk Üniversitesi Sosyal Bilimler Enstitüsü, Erzurum 2003.

Çepni S. \& Azar A. (1995). "Two Approaches to the International Initial Science Teacher Education Program”. Teacher Training for the Twenty First Century (1995) 65-77.

Dart B., Boultan-Lewis G. M., Brownlee J. M. \& Mccrindle A. R. (1998). "Change in Knowledge of Learning and Teaching Through Journal Writing”. Research Papers in Education 13/3 (1998) 291-318.

Davis E. A. (2004). "Knowledge Integration in Science Teaching: Analysing Teachers' Knowledge Development”. Research in Science Education 34/1 (2004) 21-53.

Demirtaş H. \& Özer N. (2007). "Öğretmen Adaylarının Zaman Yönetimi Becerileri ile Akademik Başarısı Arasındaki İlişki”. Eğitimde Politika Analizleri ve Stratejik Araştırmalar Dergisi 2/1 (2007) 34-47.

Deng Z. (2007). "Knowing the Subject Matter of a Secondary-School Science Subject”. Journal of 
Curriculum Studies 39/5 (2007) 503-535.

Derrington C. \& Goddard H. (2008). Whole-Brain Behaviour Management in the Classroom: Every Piece of the Puzzle. London 2008.

Dewey J. (1933). How We Think: A Restatement of the Relation of Reflective Thinking to the Educative Process. Boston 1933.

Edwards C. (1997). Classroom Discipline and Management. New Jersey 1997.

Ekborg M. (2005). “Student-Teachers’ Learning Outcomes during Science Subject Matter Courses”. International Journal of Science Education 27/14 (2005) 1671-1694.

Ekşi G. (2012). "Implementing an Observation and Feedback Form for More Effective Feedback in

Microteaching”. Education and Science 37/164 (2012) 267-282.

Emmer E. T., Evertson C. \& Worsham M. E. $\left(2000^{5}\right)$. Classroom Management for Secondary Teachers Boston 2000.

Englehart D. (2008). An Exploration of How Pre-Service Early Childhood Teachers Use Educative Curriculum Materials to Support Their Science Teaching Practices. Doctoral Dissertation. The University of Central Florida, The College of Education, Orlando, Florida 2008.

Ekiz D. (2003). “Sınıf Öğretmeni Adaylarının Öğretmen Eğitimindeki Modeller Hakkında Düşünceleri”. Milli Ĕgitim Dergisi 158 (2003) 146-160.

Ekiz D. (2006). "Self-Observation and Peer-Observation: Reflective Diaries of Primary StudentTeachers”. Elemantary Education Online 5/1 (2006) 45-57.

Erden M. (2008). Sinıf Yönetimi. Ankara 2008.

Farrell T. S. C. \& Ives J. (2015). "Exploring Teacher Beliefs and Classroom Practices Through Reflective Practice: A Case Study”. Language Teaching Research 19/5 (2015) 594-610.

Fernandez-Balboa J. M. \& Stiehl J. (1995). "The Generic Nature of Pedagogical Content Knowledge among College Professors”. Teaching and Teacher Education 11/3 (1995) 293-306.

Freidson E. (1994). Professionalism Reborn: Theory, Prophecy and Policy. Cambridge 1994.

Freire P. (1970). The Pedagogy of the Oppressed. New York 1970.

Gall M., Borg W. \& Gall J. P.(1996 $\left.{ }^{8}\right)$. Educational Research: Competencies for Analysis and Application. NewJersey 1996.

Ganesh B., \& Matteson M. S. (2011). "The Benefits of Reteaching Lessons in Preservice Methods Classes". Action in Teacher Education 32/4 (2011) 52-60.

Gençtürk E., Akbaş Y. \& Kaymakçı S. (2012). "Sosyal Bilgiler Öğretmen Adaylarının Bakış Açısıyla İdeal Öğretmenin Özellikleri”. Kuram ve Uygulamada Eğitim Bilimleri 12/2 (2012) 1559-1572.

Gilles C., Cramer M. \& Hwang S. (2001). "Beginning Teacher Perceptions of Concerns: A Longitudinal Look at Teacher Development". Action in Teacher Education 23/3 (2001) 92-98.

Güçlü N. (2001). “Zaman Yönetimi”. Kuram ve Uygulamada Eğitim Yönetimi 7/1 (2001) 87-106.

Gül G. (2002). İlköğretim Öğretmen Adaylarının ve Öğretmenlerinin Kişilik Özellikleri. Yüksek lisans tezi. İstanbul Üniversitesi Eğitim Bilimleri Enstitüsü, İstanbul 2002.

Günçer B. (1997). Okullarda Uygulama Çalışmalart-İlköğretim, Milli Eğitimi Geliştirme Projesi Hizmet Öncesi Öğretmen Eğitimi. Ankara 1997.

Güneş F. (2007). Yapılandırıcı Yaklaşımla Sinıf Yönetimi. Ankara 2007.

Güney K. (2008). Mikro-Yansıtıcı Öğretim Yönteminin Öğretmen Adaylarının Sunu Performansı ve Yansitıcı Düşünmesine Etkisi. Doktora Tezi. Firat Üniversitesi Sosyal Bilimler Enstitüsü, Elazığ 2008.

Harford J. \& MacRuaric G. (2008). "Engaging Student Teachers in Meaningful Reflective Practice”. Teaching and Teacher Education 24/7 (2008) 1884-1892.

Harlow B. D. (2007). From Learning Science to Teaching Science: What Transfers?. Doctoral Dissertation. University of Colorado, School of Education, Boulder 2007.

Hartzler-Miller C. (2002). "Teaching for Social Change: The Interplay of Social Knowledge, Content Knowledge and Personal Biography”. The International Social Studies Forum 2/2 (2002) 141-155.

Hattie J. \& Timperley H. (2007). “The Power of Feedback”. Review of Educational Research 77/1 (2007) 
81-112. DOI: $10.3102 / 003465430298487$.

Higgins A. \& Nicholl H. (2003). “The Experiences of Lecturers and Students in the Use of Microteaching as a Teaching Strategy”. Nurse Education in Practice 3/4 (2003) 220-227.

Huey-Ling L. \& Gorrell J. (2002). “The Road to Preservice Teachers’ Conceptual Change”. Educational Research Quarterly 26/2 (2002) 54-65.

Hynes M. M. (2009). Teaching Middle-School Engineering: An Investigation of Teachers' Subject Matter and Pedagogical Content Knowledge. Doctoral Dissertation. Tufts University, Math, Science, Technology and Engineering Education, Medford, MA 2009.

Kelly J. A. (1998). Social-Skills Training - A Practical Guide for Interventions. New York 1998.

Koballa T., Graber W., Coleman D. \& Kemp A. (1999). "Prospective Teachers' Conceptions of the Knowledge Base for Teaching Chemistry at the German Gymnasium”. Journal of Science Teacher Education 10/4 (1999) 269-86.

Koç C. \& Yıldız H. (2012). “Öğretmenlik Uygulamasının Yansıtıcıları: Günlükler”. Eğitim ve Bilim 37/164 (2012) 223-236.

Kolb D. (1984). Experiential Learning: Experience as a Source of Learning and Development. New Jersey 1984.

Korthagen F. A. J., Kessels J., Koster B., Lagerwerf B. \& Wubbels T. (2001). Linking Theory and Practice: The Pedagogy of Realistic Teacher Education. Mahwah, NY 2001.

Korthagen F. \& Vasalos A. (2005). "Levels in Reflection: Core Reflection as a Means to Enhance Professional Development”. Teachers and Teaching: Theory and Practice 11/1 (2005) 47-71.

Kukanauza de Mazeika J. M. (2001). Effect of Different Types of Feedback during Microteaching Sessions on Preservice Teachers. Doctoral Dissertation. New York University, New York 2001.

Krueger R. A. \& Casey M. A. $\left(2000^{3}\right)$. Focus Groups: A Practical Guide for Applied Research. Thousand Oaks, CA 2000.

Lederman N. G., Gess-Newsome J. \& Latz M. S. (1994). “The Nature and Development of Pre-Service Science Teachers' Conceptions of Subject Matter and Pedagogy.” Journal of Research in Science Teaching 31/2 (1994) 129-146.

Lee E., Brown M. N., Luft J. A., \& Roehrig G. H. (2007). “Assessing Beginning Secondary Science Teachers’ PCK: Pilot Year Results”. School Science and Mathematics 107/2 (2007) 52-60.

Linn R. L. \& Miller M. D. (2005 $)$. Measurement and Assessment in Teaching. Upper Saddle River, New Jersey 2005.

Lock L. C. \& Lee W. M. (2001). “Teaching Mathematics: What Teachers Say, Believe and Do”. Mathematics and Technology Education 1/3 (2001) 305-317.

Martinez-Pons M. (2001). The Psychology of Teaching and Learning: A Three-Step Approach. London 2001.

McMillan J. H. $\left(2000^{3}\right)$. Educational Research: Fundamentals for the Consumer. New York 2000.

Mishra P. \& Koehler M. J. (2006). “Technological Pedagogical Content Knowledge: A Framework for Teacher Knowledge”. Teachers College Record 108/6 (2006) 1017-1054.

Misra R. \& McKean M. (2000). “College Students’ Academic Stress and its Relation to Their Anxiety, Time Management, and Leisure Satisfaction”. American Journal of Health Studies 16/1 (2000) 41-51.

Missouri Teacher Standards (MTS). (2011). Kaynak: http://dese.mo.gov/eq/eses/documents/TeacherStand ardsContinuum.pdf.

Moore K. D. $\left(2007^{6}\right)$. Classroom Teaching Skill. New York 2007.

Morine-Dershimer G. \& Kent T. (1999). "The Complex Nature and Sources of Teachers' Pedagogical Knowledge”. Eds. J. Gess-Newsome \& N. Lederman. Examining Pedagogical Content Knowledge: The Construct and its Implications for Science Education (1999) 21-50. Dordrecht.

National Board for Professional Teaching Standards (NBPTS). (2003). Adolescence and Young Adulthood Science Standards. Kaynak: http://www.nbpts.org.html.

National Council for Accreditiation for Teacher Education (NCATE). (2008). Proffesional Standards for the Accredition of Teacher Preparation. Kaynak: http://www.qu.edu.qa/offices/vpcao/documents/acc 
reditation/NCATE_Standards_2008.pdf.

Nwogu S. A. (2000). “Language Barrier to Education”. Journal of Teaching 12/1 (2000) 62-71.

Oliver J. S. (1993). "Using Organized Distractions in Microteaching with Pre-Service Science Teachers”. Journal of Science Teacher Education 4/3 (1993) 77-78.

Öğretmen Yetiştirme ve Eğitimi Genel Müdürlüğü (OYEGM). (2008). Öğretmenlik Mesleği Genel Yeterlilikleri. Kaynak: http://otmg.meb.gov.tr/YetGenel.html.

Parker J. \& Heywood D. (2000). "Exploring the Relationship between Subject Knowledge and Pedagogic Content Knowledge in Primary Teachers' Learning about Forces”. International Journal of Science Education 22/1 (2000) 89-111.

Patton M. Q. (2001'). Qualitative Research and Evaluation Methods. Thousand Oaks, CA 2001.

Quirk M. (2006). Intuition and Metacognition in Medical Education: Keys to Developing Expertise. New York, NY 2006.

Rodgers C. (2002). "Defining Reflection: Another Look at John Dewey and Reflective Thinking". Teachers College Record 74/4 (2002) 842-866.

Saka M. \& Sürmeli H. (2010). "Examination of Relationship between Preservice Science Teachers' Sense of Efficacy and Communication Skills". Procedia Social and Behavioral Sciences 2/2 (2010) 47224727.

Schön D. (1987). Educating Reflective Practitioner. London 1987.

Seghedin E. (2012). "Communication-the Main Component of Teaching Competence”. Procedia Social and Behavioral Sciences 69 (2012) 350-358. DOI: 10.1016/j.sbspro.2012.11.420.

Seputro T. T. (1998). "The Influence of the Teacher's Subject Matter Knowledge and Beliefs on Teaching Practices: A Case Study of an Indonesian Teacher Teaching Graph Theory in Indonesia”. Kaynak: http://education.curtin.edu.au/waier/forums/1998/seputro.html.

Shi X. (2004). "Developing Professional Capacities of Practice Teachers in Physical Education through Reflective Teaching”. Journal of Beijing Sport University 27/2 (2004) 238-240.

Shulman L. S. (1987). "Knowledge and Teaching: Foundation of New Reform". Harvard Educational Review 57/1 (1987) 1-23.

Spraker E. R. (2010). Changes in High School Chemistry Teacher Beliefs and Practice After a Professional Development Program. Doctoral Dissertation. University of South Carolina, College of Education, Columbia, SC 2010.

Temizyürek K. (2003). Fen Öğretimi ve Uygulamaları. Ankara 2003.

The National Science Teachers Associaton (NSTA).(2003). "Standards for Science Teacher Preparation”. Kaynak: http://www.nsta.org/pdfs/NSTAstandards2003.pdf.

The National Science Teachers Associaton (NSTA).(2011). "Initial Licensure for Science Teacher Preparation”. Kaynak: http://www.nsta.org/pd/ncate/docs/2011nstastandardsonly.pdf.

The University of North Caroline at Pembroke (UNCP).( 2011). “Teacher Education Program”. Kaynak: http://ebookbrowse.com/uncp-teacher-education-program-candidate-standards-doc-d122015582.

Tran L. U. \& King H. (2007). "The Professionalization of Museum Educators: The Case in Science Museums”. Museum Management and Curatorship 22/2 (2007) 129-147.

Training and Development Agency for Schools (TDA). (2007). "Proffesional Standards for Teachers. Why Sit Still in Your Carerer?”. Kaynak: http://www.tda.gov.uk/standards.

Tschannen-Moran M., Hoy W. A. \& Hoy W. K. (1998). “Teacher Efficacy: Its Meaning and Measure”. Review of Educational Research 68/2 (1998) 202-248.

Tuan H. L. (1996). "Investigating the Nature and Development of Pre-Service Chemistry Teachers' Content Knowledge, Pedagogical Knowledge and Pedagogical Content Knowledge”. Proceeding of the National Science Council Part D: Mathematics, Science and Technology Education 6/2 (1996) 101-112.

Tutkun O. F. (2015). "Prospective Teacher’s Communication Skills Level: Intellectual, Emotional and Behavioral Competencies”. Anthropologist 19/3 (2015) 665-672.

Uline C., Wilson J. D. \& Cordry S. (2004). "Reflective Journals: A Valuable Tool for Teacher Preparation”. 
Education 124/3 (2004) 456-460.

Usher E. L. \& Pajares F. (2008). "Sources of Self-Efficacy in School: Critical Review of the Literature and Future Directions”. Review of Educational Research 78/4 (2008) 751-796.

Uşak M. (2005). Fen Bilgisi Öğretmen Adaylarının Çiçekli Bitkiler Konusundaki Pedagojik Alan Bilgileri. Doktora Tezi. Gazi Üniversitesi, Eğitim Bilimleri Enstitüsü, Ankara 2005.

Üstün A. (2002). "Eğitimin Ekonomik Temelleri”. Ed. E. Toprakçı. Eğitim Üzerine (2002) 246. Ankara.

Volante L. \& Fazio X. (2007). "Exploring Teacher Candidates' Assessment Literacy: Implications for Teacher Education Reform and Professional Development”. Canadian Journal of Education 30/3 (2007) 749-770.

Wallace M. (1991). Training Foreign Language Teachers: A Reflective Approach. Cambridge 1991.

Wang H. L. (2005). Early Childhood Educators' Perceptions of Professional Competence in Preschool Settings. Unpublished Doctoral Dissertation. The Pennsylvania State University, University Park, PA 2005.

Wubbels T., Brekelmans M., den Brok P. \& van Tartwijk J. (2006). “An Interpersonal Perspective on Classroom Management in Secondary Classrooms in the Netherlands”. Eds. C. Evertson \& C. Weinstein. Handbook of Classroom Management: Research, Practice, and Contemporary Issues (2006) 1161-1191. Mahwah, NJ.

Yalın H. $\left(2004^{10}\right)$. Öğretim Teknolojileri ve Materyal Geliştirme. Ankara 2004.

Yeşilyurt E. (2012). "Fen ve Teknoloji Dersinde Kullanılan Ölçme Değerlendirme Yöntemleri ve Karșlaşılan Güçlükler”. Turkish Studies- International Periodical for The Languages, Literature and History of Turkish or Turkic 7/2 (2012) 1183-1205.

Yiğit N. (2010). "Developing Presentation Skills of Student Teachers through Micro-Teaching Method”. Energy Education Science and Technology Part B-Social and Educational Studies 2/1-2 (2010) 55-74.

YÖK/Dünya Bankası (1998). Fakülte-Okul İşbirliği: Milli Ĕgitimi Geliştirme Projesi Hizmet Öncesi Öğretmen Eğitimi. Ankara 1998.

Zhang Z. \& Burry-Stock J. A. (2003). “Classroom Assessment Practices and Teachers' Self-Perceived Assessment Skills”. Applied Measurement in Education 16/4 (2003) 323-342. 